\title{
A Conceptual Framework for Describing Selected Urban and Community Impacts of Federal Energy Policies
}
F. A. Morris
A. A. Marcus
D. Keller

June 1980

Prepared for the U.S. Department of Energy

Assistant Secretary for Environment Office of Environmental Assessments under Contract DE-AC06-76RLO 1830

Pacific Northwest Laboratory Operated for the U.S. Department of Energy by Battelle Memorial Institute

\section{* Baltelle}


NOTICE

This report was prepared as an account of work sponsored by the United States Government. Neither the United States nor the Department of Energy, nor any of their employees, nor any of their contractors, subcontractors. or their employees, makes any warranty, express or implied, or assumes any legal liability or responsibility for the accuracy, completeness or usefulness of any information, apparatus, product or process disclosed, or represents that its use would not infringe privately owned rights.

The views, opinions and conclusions contained in this report are those of the contractor and do not necessarily represent those of the United States Government or the United States Department of Energy.

\author{
PACIFIC NORTHWEST LABORATORY \\ operated by \\ BATTELLE \\ for the \\ UNITED STATES DEPARTMENT OF ENERGY \\ Under Contract DE-AC06-76RLO 1830
}

\author{
Printed in the United States of America \\ Available from \\ National Technical Information Service \\ United States Department of Commerce \\ 5285 Port Royal Road \\ Springfield, Virginia 22151
}

Price: Printed Copy $\$$

$\because$ Microfiche $\$ 3.00$

$\begin{array}{cc}\text { *Pages } & \begin{array}{c}\text { NTIS } \\ \text { Selling Price }\end{array} \\ & \\ 001-025 & \$ 4.00 \\ 026-050 & \$ 4.50 \\ 051-075 & \$ 5.25 \\ 076-100 & \$ 6.00 \\ 101-125 & \$ 6.50 \\ 126-150 & \$ 7.25 \\ 151-175 & \$ 8.00 \\ 176-200 & \$ 9.00 \\ 201-225 & \$ 9.25 \\ 226-250 & \$ 9.50 \\ 251-275 & \$ 10.75 \\ 276-300 & \$ 11.00\end{array}$




\section{7}

\section{A CONCEPTUAL FRAMEWORK FOR DESCRIBING SELECTED URBAN AND COMMUNITY IMPACTS OF FEDERAL ENERGY POLICIES}
F. A. Morris (a)
A. A. Marcus (a)
D. Keller (a)

June 1980

Prepared for the U.S. Department of Energy Assistant Secretary for Environment Office of Environmental Assessments under Contract DE-AC06-76RLO 1830 Jerome Hinkle, Project Monitor Regional Impacts Division

Pacific Northwest Laboratory Richland, Washington 99352

(a) Battelle Human Affairs Research Centers Seattle, Washington 98105 
1.0 ACKNOWLEGEMENTS ................. i

1.0 INTRODUCTION . . . . . . . . . . . . . I

2.0 NEIGHBORHOOD STABILITY . . . . . . . . . . . 6

2.I DEFINITION AND MEASURE . . . . . . . . . . 6

2.2 DETERMINANTS . . . . . . . . . . . . . . . . 12

2.2.I Metropolitan Growth and Development : - I2

2.2 .2 Neighborhood Location ......... . 14

2.2.3 Neighborhood Characteristics...... . I5

2.2.4 Individual and Household Decisions . . . 17

2.2.5 External Organizations . . . . ... 19

2.2 .6 Summary .. . . . . . . . . . . 21

2.3 IMPACT OF FEDERAL ENERGY POIICIES . . . . . . . 21

2.3.I Oil Price Decontrol . . . . . . . . . 22

2.3.2 Building Energy Performance Standards . . 28

2.3.3 Federal Aid for Mass Transit.... . 35

3.0 HOUS ING AVAILABILITY . . . . . . . . . . . . 45

3.I DEFINITION AND MEASUREMENT .......... 45

3.2 DETERMINANTS . . . . . . . . . . . . . 49

3.2.1 Demand . . . . . . . . . . . . . 54

3.2 .2 Supply . . . . . . . . . . . . . 59

3.2.3 Summary . . . . . . . . . . . . 62

3.3 IMPACT OF FEDERAL ENERGY POLICIES... .62

3.3.1 Oil Price Decontrol ....... 64

3.3.2 Building Energy Performance Standards . 71

3.3.3 Federal Aid for Mass Transit..... . 76

4.0 QUALITY AND AVAILABILITY OF PUBLIC SERVICES . . . . 79

4.I DEFINITION AND MEASUREMENT . . . . . . . . . 79

4.2 DETERMINANTS ................ 81

4.2.1 Public Services as Externally Determined

4.2.2 Event jublic Services as Bureaucratic output $\cdot 82$

4.2.3 Summary ........... 90

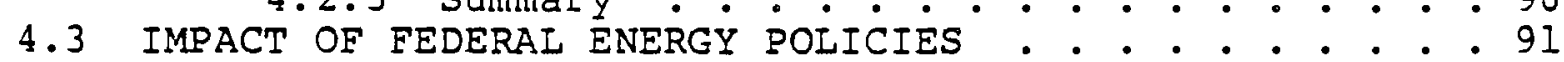

4.3.1 OiI Price Decontrol . . . . . . . . . . .91

4.3.2 Building Energy Performance Standards . . 94

4.3.3 Federal Aid to Mass Transit . . . . . 96 


\section{ACKNOWLEDGEMENTS}

The work reported here was conducted under the direction of and with funding from the U.S. Department of Energy, Office of Environmental Assessments, Regional Impacts Division. The authors wish to acknowledge the support of the Division and the guidance of the DOE project monitor, Jerome F. Hinkle, under Contract DE-AC06-76RLO-1830. We wish also to acknowledge the suggestions of Darryl Hessel (the PNL project monitor) and Christopher cluett. 


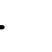




\subsection{INTRODUCTION}

Executive Order 12074 , issued by President Carter on August 16, 1978, requires executive agencies to prepare urban and community impact analyses (UCIAs) for major policy initiatives that may adversely affect cities, counties, and other communities. The Office of Management and Budget has issued guidelines for the preparation of these analyses by federal agencies. 1 These guidelines establish categories of impacts that UCIAs must address. They include impacts on employment, population, income, state and local fiscal conditions, neighborhood stability, housing availability, and quality and availability of public services. The analyses are to identify both absolute impacts and relative impacts on particular types of places, including central cities, suburban communities, nonmetropolitan communities, communities with high unemployment, and communities with low per capita income.

In preparing a pilot UCIA on synthetic fuels initiatives, the Department of Energy is using the Social and Economic Assessment Model (SEAM) to estimate impacts on employment, population, income and state and local fiscal conditions. However, SEAM has only Iimited relevance to impacts on neighborhood stability, housing availability, and quality and availability of public services. This report is designed to help fill that gap by providing a conceptual framework for describing the impacts of federal energy policies with respect 
to those categories. To be consistent with DOE's approach to estimating urban and community impacts in other categories (which involves estimating absolute impacts in several "case study" communities and then comparing the results to estimate relative impacts on different types of communities), this framework is primarily designed to help describe the impacts of a policy on a given community. The results obtained from applying the framework to several communities may then be compared to describe relative impacts on different types of communities.

This framework is based on a very simple causal "model." The first part of the model appears in Figure 1.I. The outputs of the model are impacts--changes in the state of the world of particular interest to policymakers. In this case, the impact categories are neighborhood stability, housing availability, and quality and availability of public services. At any given time, a set of determinants account for the state of the world with respect to an impact category. In statistical jargon, determinants are the "independent variables" and the impact category is the "dependent variable."

For example, if the impact category is quality and availability of public services (defined and measured as overall expenditures on public services), the principal determinants are said to be per capita income, intergovernmental revenue, population density, and nonresident population. 2 


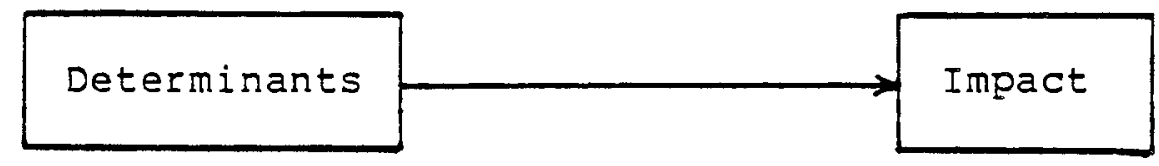
(E.g., per capita
income, intergovernmental revenue, population density,
(E.g., quality and availability of public services) nonresident population)

FIGURE 1.1. Determinants of Urban and Community Impacts

This model can be expanded to help describe the impacts of a particular policy, as illustrated in Figure 1.2. One starts with a federal policy, such as oil price decontrol. One then identifies the effects of the policy, as projected in environmental impact statements required by NEPA, regulatory analyses required by Executive Order 12044, and analyses

\begin{tabular}{|c|c|c|c|}
\hline Federal Policy & Effects & Determinants & Impact \\
\hline $\begin{array}{l}\text { (E.G.' oil } \\
\text { price decontrol) }\end{array}$ & $\begin{array}{l}\text { (E.g.' } \\
\text { increase in } \\
\text { inflation, } \\
\text { decline in } \\
\text { economic } \\
\text { output, } \\
\text { increase in } \\
\text { unemployment } \\
\text { decline in } \\
\text { real income) }\end{array}$ & $\begin{array}{l}\text { (E.g., per capita } \\
\text { income, inter- } \\
\text { governmental } \\
\text { revenue, population } \\
\text { density, non- } \\
\text { resident } \\
\text { population) }\end{array}$ & $\begin{array}{l}\text { (E.g.' } \\
\text { quality } \\
\text { and } \\
\text { avail- } \\
\text { ability } \\
\text { of public } \\
\text { services) }\end{array}$ \\
\hline
\end{tabular}

EIGURE 1.2. Causal Model 
prepared by such offices as the Congressional Budget office (CBO). For example, in the case of oil price decontrol, CBO has stated that major effects would include an increase in inflation, a decline in economic output, an increase in unemployment, and a decline in real income. ${ }^{3}$ For purposes of analyzing a particular category of urban and community impact, such as quality and availability of public services, two kinds of effects are important: (1) any effect that itself constitutes an urban and community impact, and (2) those effects that are independent variables previously identified as determinants. The first category of effect one simply reports. The second category of effects leads one to make appropriate adjustments to the corresponding determinants in order to calculate the impact. Any difference in the value of the impact category adjusted for policy effects and the value of the impact category in the absence of the policy initiatiave constitutes the urban and community impact for that category. For example, oil price decontrol has the effect of reducing real income. Income is one determinant of the quality and availability of public services. Thus oil price decontrol may reduce quality and availability of public services if the effect of reduced income is not offset by effects that change the value of other determinants of quality and availability of public services. 
Application of the model to a particular impact category thus first requires the following steps:

establishing a definition and measure for the
impact category
- identifying the determinants of these impacts

These steps provide essential background for analyzing any policy's urban and community impact with respect to the impact category. Analysis of the impact of a particular policy requires the following addtional steps:
- identifying the policy
- identifying its effects (as estimated by others)
- isolating any effects that themselves constitute an urban and community impact
- identifying any effects that change the value of determinants
- describing the impact with reference to the new values of determinants

This report provides a framework for these steps. The framework does not contain formulas that can be applied mechanically to estimate impacts. Rather, it provides a consistent logic for describing impacts qualitatively. Thus for example, the analyst applying the framework may not know the preexisting value of a determinant such as construction costs. He or she should be able to surmise however, that a policy effect, such as greater use of insulation, may be expected to increase construction costs whatever their 
preexisting value. The analyst will also have to reach qualitative judgments about the net result of positive and negative changes in determinants. What the framework provides is a way of reasoning through these problems.

This report develops the framework as follows. Each succeeding chapter addresses one of the three impact categories: neighborhood stability, housing availability, and quality and availability of public services. In each chapter, we specify a definition and measure for the impact; identify its principal determinants; and demonstrate how the causal model can be used to estimate impacts by applying it to three illustrative federal policies: domestic oil price decontrol, building energy performance standards, and increased federal aid for mass transit. 


\subsection{NEIGHBORHOOD STABILITY}

\section{I DEFINITION AND MEASURE}

Neighborhood stability has become the focus of increasing attention and concern over the last two decades from urban residents, city officials, and federal policymakers alike. Residents desire to maintain an adequate and stable quality of life. City officials recognize that neighborhood stability influences the vitality of local business and industry. Federal policymakers understand that urban and community problems affect the health of the national economy.

The neighborhood as a concept is essentially unique to cities. However, a neighborhood is more than simply an area in a city where people live and interact with each other; it is also a social entity. The neighborhood thus has both physical. and symbolic boundaries. ${ }^{1}$ The residents of the neighborhood internalize, to varying degrees, symbolic identification with their neighborhood. Where you live says something to other people about the kind of person you are.

Because the neighborhood is defined along these two very different dimensions of spatial and social characteristics, it is hard to obtain universal agreement about where neighborhood boundaries lie. The city may define the boundaries one way for functional purposes (assessments, garbage collection, voting districts, etc.), while the residents may define it differently in terms of friendship patterns, housing type or appearance, 
ethnic types, etc. Residents of declining inner-city neighborhoods proclaim in local and national for uns that "It's people. It's family. It's a sense of community." 2 Most would agree that the neighborhood as both a spatial and social unit is a local community or smaller version of it such as the social block which reflects face to face daily interaction, social solidarity, and patterns of self-help. $3,4,5$

The stability of the urban neighborhood is perhaps most directly defined in terms of its presumed position on a continuum from no change to substantial change. According to one analyst, "stability means continuity, survival, permanence, security, and social cohesion . . . "6 strictly speaking it is hard to imagine a neighborhood that experiences no change for anything but a very short period of time. The definitional problem really focuses on two issues: (1) what are the dimensions along which change should be assessed? and (2) how much change or what rapidity of change is necessary to cause a level of instability that would be defined as a significant urban impact?

In dealing with the first question it is clear that individual neighborhood residents and the neighborhood in aggregate must be treated separately. A convenient way of understanding change in these two aspects is the life-cycle model. 7,8,9 Many neighborhoods have been shown to progress through stages of transition as cities grow from the center out and individuals move in or out. These changes are related to 
the segregation of social and ethnic groups in cities, to the age and cost of housing, to changes in central city land values, and to improvements in transportation that have allowed some workers to reside far from their place of employment. Historically, small rural communities achieved a high level of stability that persisted for long periods of time. The processes of industrialization and urbanization have not only disrupted many rural and small town communities but have also created new neighborhood forms within cities that are more complex than their rural counterparts. It is possible that increased size, density and heterogeneity of communities would cause rapid change by depersonalizing social interactions. But often an urban neighborhood achieves great permanence as "an ongoing system of social networks into which new generations and new residents are assimilated, while the community itself passes through its own life cycle." 10

Stability is thus a function of change in population size and composition as well as the community's position within the urban environment. Established neighborhoods may experience population succession and grow or decline in size while still preserving the functional relations between residents, the neighborhood's organizational structures, and links with the system outside the neighborhood (e.g., city government, other neighborhood organizations, or federal programs). For example, one aspect of neighborhood stability is the integrity of its organizations (formal, such as schools, and informal, such as 
recreational clubs). Clearly organizations can flourish even though their individual members come and go. So when looking at stability, it is useful to distinguish neighborhood structure (what are its organizational elements and how are they interrelated), neighborhood function (what services are provided; what does neighborhood residence mean for the resident; how does the neighborhood interact with organizations external to it in the urban environment), and finally neighborhood membership (how similar or different are members of the neighborhood to each other and compared with outsiders; what stage of the individual life-cycle are they in, for example: single, students, married, working, with children, retired, elderly; what is the status level of neighborhood residents; what positions do they occupy in the larger city; how strong an attachment do they feel for their neighborhood).

In short, social and economic change do not by themselves constitute neighborhood instability. The impacts of federal policies on neighborhood stability should be evaluated in terms of disruptions in the structure, function, and cohesion of the neighbor hood.

Numerous indicators or measures have been used to deal with the concept of stability. In terms of the strength of attachment of members to their neighborhood, measures include numbers of friends and relatives in the neighborhood, membership in formal and informal organizations, and expressed interest in the community.ll community cohesion can also be 
investigated by focusing on physical and social networks. 12 Instability results to the extent that a policy or project interferes with population mobility or with the ability of neighbors to freely interact in expected or traditional patterns. Another indicator of neighborhood stability, for which data are more readily available, is length of residence of individual members. The assumption is that high levels of population mobility (eighteen percent of the U.S. population is estimated by the U.S. Census to have changed residence in 1970) ${ }^{13}$ reflect dissatisfaction with some places of residence. However, even moderate levels of mobility can affect neighborhood stability in different ways. For example, stable, low density, high social service communities are attractive to inmigrants, and the wave of newcomers could enhance neighborhood stability in terms of economic strength, political power, and social organizations. On the other hand, neighborhoods with a history of stability and homogeneity of membership could be severely disrupted by a flood of newcomers. Such is the case with energy boom-town growth which draws transient workers with different backgrounds into established communities. Crime and delinquency rates may increase. There may also be increases in mental health problems, feelings of disorientation on the part of oldtimers, shifts in the locus of political power, and deterioration of housing and the quality of the environment. 
Instability may also occur when a neighborhood experiences great outmigration and falls into physical, social, and psychic disrepair. As upwardly mobile citizens have moved from central cities to suburban residences, they often leave behind them dying neighborhoods, inhabitated by the poor, minorities, and the elderly who cannot afford to leave and cannot afford to upgrade the quality of their environment on their own. Housing values decline as dwelling units fall into disrepair, home owners are replaced by slum landlords, banking institutions refuse to invest in these high risk neighborhoods, and social service costs rise. These disruptions in neighborhood structure and function further increase the tendency for outsiders to avoid such neighborhoods. With this scenario in mind, urban planners have classified neighborhoods along a continuum from flourishing and healthy through weakening or declining to dying or abandaned.14,15

Neighborhood stability can in fact occur at any point along this range of neighborhood health at a point when a balance has been achieved between the costs to residents of staying in the neighborhood (monetary costs such as housing prices and taxes, and non-monetary costs such as social status, convenience, and services) and the ability or willingness of residents to bear these costs. Policy can intervene to help achieve such stability. Housing can be rennovated, aid can be made available, policies can be adjusted, and confidence can be restored. The best evidence of this today is in the renewed 
interest in rebuilding old, run-down sections of central city neighborhoods. Such federal programs as Urban Renewal, Model Cities, and the Housing and Community Development Act, while not fully successful, are both a response to and a cause of increased recognition that neighborhood stability is important.

\subsection{DETERMINANTS}

Factors that influence the stability of urban neighborhoods fall into two general categories. They are (1) structural or environmental factors and (2) individual, organizational, or technological factors. Energy policy impacts on neighborhood stability are likely to occur primarily through the second category of factors. The first set of factors tend to be the product of historical conditions that serve to constrain in certain predictable ways the potential for neighborhood change.

\subsubsection{Metropolitan Growth and Development}

The age, size, rate of growth, geographic location of an urban center and concentration of its populations are all structural attributes of the urban area that influence the stability of neighborhoods which it contains. Trends in metropolitan growth have been changing dramatically over the last decade. "For the first time in this century, and probabjy in the nation's history, more Americans are moving away from metropolitan areas than are moving to them in an abrupt and baffling reversal of the long established trend to 
urbanization."16 The development of urban areas in this century has involved a pattern of growth that centered on a dominant central business district with people's residential location determined by means of transportation and the centralization of jobs. The classical theory of urban growth developed by the Chicago school of urban research early in this century suggested that people moved successively away from the central business district with urban population growth, being replaced by new, lower class inmigrants. ${ }^{17}$ with the development and rapid acquisition of the private automobile, not only did suburban neighborhoods arise and flourish, but new dispersed centers of commercial and industrial activity arose. ${ }^{18}$ In the last decade there has been a notable shift of metropolitan populations from the northeast and northcentral cities to southern states. ${ }^{19}$ And, as noted above, more people than ever before are leaving metropolitan areas, both central cities and suburbs, for residence in nonmetropolitan areas. The big losers, however, have been the central cities of metropolitan areas located in certain regions of the country, in particular the large northern central cities. It is the neighborhoods in these cities that can be expected to be the least stable in the sense that they are most likely to be losing population. In addition, these tend to be older cities, with less desirable housing in their urban centers, and high concentrations of minority groups. 
Location in older, larger, northern, and declining metropolitan areas increases the chances that neighborhood instability will increase. While federal policy obviously cannot alter the age or location of the urban area, it may have an effect on the rate of change in population size or the nature of population concentration, and thereby on the stability of those neighborhoods.

\subsubsection{Neighborhood Location}

Neighborhood location in suburban or central city locations is another determinant of stability. While central cities have on balance been losing population, suburban neighborhoods have been gaining. Most recent concern with neighborhood stability has focused on declining or rundown neighborhoods in or near the core areas of large cities. The logic for increased assistance often places central city and suburban neighborhoods in competition. Stability is said to be possible when the central city neighborhood "possesses capabilities to compete well with its suburbs as a place to live, to support a high level of economic opportunity and employment, and to meet its fiscal needs without subsidies from other communities." 20

People choose a place of residence primarily for economic reasons; they desire to live close to their job while at the same time satisfying their strong preference for residence in small, non-urban places. 21 Thus, many people choose suburban neighborhoods within a reasonable commuting distance of their 
place of work. Some types of work are best suited to centralized location (professional, and administrative jobs in particular) while others are readily decentralized (mostly service related jobs). While the former type tend to flourish in centrally located high-use complexes, their employees disproportionately choose suburban residences. The other side of the coin is that the current residents of central city neighborhoods are largely unable to contribute to the economic viability of the city. ${ }^{22}$ This is precisely the objective of numerous local and federal programs designed to infuse new life into old neighborhoods.

\subsubsection{Neighborhood Characteristics}

Housing quality and its effects on individual residential satisfaction are especially important determinants of neighborhood stability. $23,24,25$ Residential satisfaction, broadly defined, determines individual and household choices to stay or move, as discussed in section 2.2.4. There are numerous dimensions along which neighborhoods may be characterized, including housing, services, population, and the quality of the environment. Neighborhoods that are centralized in the city tend to have older, multiple unit, crowded housing facilities while suburban housing tends to be newer, single family, owner occupied, and more spacious. This characteristic of urban neighborhoods significantly influences the type and distribution of households throughout the city. Families in 
the early stages of their life-cycle (especially childbearing years) tend to locate in decentralized neighborhoods while non-married individuals tend to be more centrally located. Thus residential turnover is likely to be high in neighborhoods with higher proportions of rental housing; they are inherently less stable.

As Gerald Suttles argues, neighborhoods respond differently to population turnover. 26 The "defended neighborhood," for example, protects itself from change likely to cause instability by establishing restrictions to membership and a powerful set of social norms governing behavior (for example, a high-class fenced-in neighborhood or an ethnic ghetto). The segregation of people along class or ethnic lines is a well-established characteristic of the internal structure of cities, and segregated neighborhoods tend to be stable for long periods of time (at least with respect to their urban boundaries and identity, if not with respect to internal turmoil). Other characteristics of the neighborhood that could influence its stability include the price of housing and the value of land, both of which are related to location. As the price of housing increases along with rising incomes, families will be induced to take their profits and upgrade their housing by moving to a "better" neighborhood, usually meaning a more decentralized location in a suburban neighborhood.

Neighborhood amenities such as recreational facilities, high quality public services, lack of noxious industry, and 
desirable physical environment are attractive residential features that decrease the likelihood of rapid change. The characteristics of residents interact with characteristics of the neighborhood. Middle income residents have the ability to maintain home and property. Central city neighborhood residents may not lack the desire but they often lack the resources to prevent the increasing decay of their housing and their neighborhood.

\subsubsection{Individual and Household Decisions}

To this point, we have emphasized the importance of the urban and neighborhood environment in conditioning decisions that are constantly being made by people about housing. These housing location decisions are the driving force behind neighborhood change. Neighborhood health and stability largely depend on them. As one analyst has observed, "the high rate of mobility of the American people affects all

neighborhoods . . . No neighborhood is truly stable except a cemetery with all burial lots filled." 27 while, on the average, urban neighborhoods experience residential turnover at an annual rate of 20 percent and of ten 50 percent or more in a five year period, 28 some neighborhoods clearly change their resident population much more rapidly.

People move between urban areas primarily in response to employment. However, they are often able to move within an urban area in order to upgrade their housing and general 
quality of life without changing jobs. This process of social upgrading leads to some amount of churning of the populations of most residential neighborhoods. Nonetheless, some neighborhoods will have the absorptive capacity to maintain stability of services and social vitality, in spite of population change, while others will not.

The household's decision to upgrade, whereby residents seek to improve their housing and quality of life, is supported by a rising income structure and urban policies that encourage the creation and maintenance of desirable suburban residential neighborhoods. "upgrading through movement is probably the most common response to marked improvement in status and incomes by individual households in U.S. metropolitan areas." 29 As metropolitan growth declines, there are fewer candidates to replace those who have left, resulting in the inevitable creation of inner-city neighborhoods characterized by old, low cost, poor quality housing in poverty areas. This process manifests itself in terms of residential segregation of minority groups in unstable, undesirable, rundown neighborhoods. Such neighborhoods are costly to service, and they tend to drive out needed commercial enterprise. Serious costs also accrue to residents who might have preferred to stay but were forced out by policies that encouraged upgrading over rennovation of old neighborhoods. Urban planners frequently stress the desirability of households deciding to "upgrade in place." This requires a portion of the neighborhood's 
residents to be upwardly mobile (i.e., to improve their job and income) but make the decision not to move. Encouraging residents to improve their neighborhood's housing stock and to strengthen their social ties with neighbors and neighborhood institutions will support neighborhood stabilization.

The decision to move represents not just one decision, but many decisions of different actors. Together, those decisions constitute the primary determinants of stability. ${ }^{30}$ The actors include not only residents and households but also non-resident building owners, bankers, real estate brokers, public officials, developers, and public service providers. " $\frac{1}{4} S \frac{1}{2} t$ rategies to intervene in the neighborhood change process can be most effective when they attempt to affect how decisions are made and alter their outcomes." 31

\subsubsection{External Organizations}

Neighborhoods have a limited ability to independently control their destiny. Stability derives not only from the factors and conditions already discussed, but also from community control over "an increasing range of exchanges and communications with other residential groups and organizations in the wider society." 32 Neighborhood identity is of ten imposed and maintained by forces and organizations external to the neighborhood. Neighborhood stability partly depends on the neighborhood's ability to obtain and maintain adequate services over time. Indicators include dollars allocated per unit of 
time, community membership on key decisionmaking bodies, and differences across communities in those indicators. Critical economic and fiscal resources are under the influence if not control of outside organizations. An example is "the controversial practice of 'redining'--the refusal of banks and savings and loan institutions to make mortgage and home-improvement loans in what they consider high-risk neighborhoods. Cities charge that this practice discriminates against a wide variety of blue-collar, minority and ethnic neighbor hoods. " 40

In a policy context, stability is a function of the capability or appropriateness of political and governmental structures to deal with neighborhood based problems. ${ }^{33}$ Many would turn the above statement around and argue that neighborhood stability is a function of the neighborhood's ability and willingness to exert control over its relationships with external organizations. $34,35,36,37$ Neighborhood decline and instability can be countered by bringing decisionmaking to neighborhood governments, increasing opportunities for neighborhood participation in the political process, and providing neighborhoods control over metropolitan resources to solve urban problems and manage social conflict.

Residents behave largely out of self-interest, often expecting more from their community than they are willing to contribute. "But more significantly, their relation to the community--their social investment--is such that when the 
community fails to serve their needs, they will withdraw. Withdrawal implies either actual departure from the local community or merely a decline in or lack of involvement." 38 Withdrawal provides the potential for instability and social disorganization. Thus efforts to increase public participation in all aspects of neighborhood and urban life are both efforts to solve problems and counter social indifference which often leads to levels of instability that cannot be reversed without substantial outside intervention.

\section{2 .6 Summary}

As summarized in Figure 2.1, the principal determinants of neighborhood stability are the urban area, neighborhood location, neighborhood characteristics, individual and household decisions, and external organizations. Of these, it is individual and household decisions that are most likely to be affected by federal policy and thus result in impacts on neighborhood stability.

\subsection{IMPACT OF FEDERAL ENERGY POLICIES}

In this section, we describe the effects of three illustrative federal policies-oil price decontrol, building energy performance standards, and federal aid to mass transit and estimate their impacts on neighborhood stability. 
Metropolitan Growth and Development

- age

- size

- rate of growth

- geographic location

\section{Neighborhood Location}

- surburban vs. central city

- distance from residence to workplace

\section{Neighborhood Characteristics}

- housing quality and availability

- housing age, price, type (own vs. rent)

- population size, composition, concentration

- public services

- transportation

- environmental quality

- organization of of neighborhood

- amenities

- dependence on outside organizations

\section{Individual and Household Decisions}

- moving vs. staying

- upgrading housing

- participation in community affairs

- neighborhood social ties

- individual life-cycle status

\section{External Organizations}

- social service agencies

- city government

- federal government

- real estate organizations

- Einancial instititutions

FIGURE 2.1 Determinants of Neighborhood Stability 


\subsubsection{Oil Price Decontrol}

On April 5, 1979, President Carter announced his intention to phase out price controls on domestic oil over the period June 1, 1979 to September 30, 1981. The President acted under the authority of the Energy Policy and Conservation Act (EPCA) of 1975, which established the current regime of price controls. Under the Act, controls would have expired in any event by October, 1981, but the President had discretion to modify or eliminate the controls beginning June 1, 1979. The President's plan redefines all old oil (which receives the lowest controlled price) as new oil between June 1, 1979, and October 1, 1981, and at the same time gradually raises the price of new oil (which receives a higher but still controlled price) in equal monthly increments until it reaches the world (uncontrolled) price by October 1, 1981. Thus, by October 1, 1981, all oil produced in the United States will receive the world market price.

The objective of oil price decontrol is to reduce domestic consumption of oil and increase domestic oil production. The Congressional Budget office has estimated that by 1985 oil price decontrol will reduce domestic consumption by 215,000 barrels per day from a total consumption of about 21 million barrels per day with continued controls. Of this savings, 85, 000 barrels per day will come from the transportation sector; 25,000 barrels per day will come from the electric utilities sector; 40,000 barrels per day will come from the residential and commercial sector; and 65,000 barrels per day 
would come from the industrial sector. ${ }^{39}$ At the same time, the CBO estimates that the President's plan will increase domestic oil supply by 205,000 barrels per day by 1981 and 405,000 barrels per day by 1985 .

In addition, oil price decontrol will have a variety of other effects, as identified by CBO. In absolute terms, oil price decontrol is expected to have relatively minor impacts on inflation (a cumulative rise of between . $6 \%$ and $.8 \%$ by the end of 1982), output of the economy (reducing output relative to the base case by less than $1 \%$ in any year), and unemployment (increasing unemployment relative to the base case by no more than . 38 in any year). Oil price decontrol is also likely to reduce real incomes -- by $\$ 12.2$ billion in 1982 (assuming constant real OPEC oil prices), by $\$ 15.8$ billion in 1982 (with an increase in real OPEC prices of $3 \%$ per year). 40 About one-third of this reduction in purchasing power will take the form of increased expenditures on gasoline and heating oil, about two-thirds will take the form of increased expenditures for the indirect use of oil.4l In percentage terms, lower income groups will be hardest hit, as apparently, will those with the relatively highest expenditures on gasoline (people Iiving outside the Northeast and people living outside SMSAs), and those with relatively highest expenditures on heating oil and kerosene (people living in the Northeast and people living outside SMSAs). In summary, the principal anticipated effects of domestic oil price include: 
1. an increase in the price of oil to world price

2. an increase in inflation 42

3. a decline in economic output 43

4. an increase in unemployment 4

5. a decline in real income, especially among families that have low incomes or use petroleum products heavily

6. increased revenues from royalty payments and severance, income, ${ }_{\text {states }}{ }^{5}$ ales, and property taxes in oil producing

When predicting negative economic effects and community disruption brought on by oil price decontrol, an important caveat must be raised. Negative economic effects of decontrol without regard to other economic conditions, may be relatively small. Recall that the Congressional Budget Office estimates only a cumulative rise in inflation of between .6 and .8 percent by the end of 1982, reductions in output of less than 1 percent per year, declines in employment of no more than .3 percent per year, and a $\$ 12.2$ billion 15.8 billion decline in real income depending on how large the increase in OPEC-set world oil prices. Without other economic forces exacerbating these conditions, the harm done to the economy by oil price decontrol may not be of such a magnitude as to cause overall instability in neighborhoods. While the direction of impacts brought on by price decontrol will be negative it is not possible to predict their size.

Areas that are losing population, such as northeastern cities, may experience different impacts than neighborhoods 
that are gaining population, such as suburbs, rural areas, and southern and western cities. Per family expenditures on home hearing oil and for petroleum generated electric power are much greater in the Northeast than in other regions of the country. On the other hand, in general, per family gasoline expenditures are greater in the south and west than they are in the North and East. They are also greater in suburban areas than in urban areas and greater still in rural areas. 46 As with expenditures of gasoline, heating oil expenditures are greater in suburban areas than in urban areas and greater still in rural areas. 47

As a consequence, oil price decontrol could have some marginal effects on residential location decisions. Higher gasoline and heating oil prices (all other things being equal) could increease the attraction of urban areas relative to suburban areas and suburban areas relative to rural areas. Less clearly, higher gaoline prices (for which expenditures are absolutely several times greater than for home heating oil) might increase the attraction of the Northeast relative to other parts of the country. The ultimate implications of these changes for neighborhood stability are not entirely clear. The areas that became relatively more attractive could also become relatively more stable, as residents choose to stay and invest in their homes and neighborhoods rather than move to the suburbs, for example. On the other hand, an influx of new residents to the more attractive neighborhoods could force out 
existing residents by bidding up land values and rents and forcing up taxes. This process of "gentrification" would destabilize neighborhoods, at least in the short run. The opposite side of the coin is less neighborhood stability in rural and suburban areas as they become relatively less attractive.

One final set of effects that oil price decontrol may have on neighborhood stability is unrelated to location decisions. Some observers have argued that the higher gasoline prices and lower real incomes resulting from increased energy prices will lead people to look increasingly to their own neighborhoods for recreation, employment, shopping, education, and political participation. 48 People would rely less on outside organizations and agencies. Cooperative endeavors like van pooling and ride sharing would develop to compensate for higher oil prices. These activities could enhance the ties of all residents to their present neighborhoods, contributing to overall neighborhood stability. To a slight degree, oil price decontrol could reinforce this tendency.

While the direction of these effects, however, is clear, their size may be small. Early predictions following the 1973 oil embarge that increased gasoline prices would lead to a major migration of middle-class residents from the suburbs to the cities have not come to pass. 49 Recent articles argue that higher gas prices will squeeze "spread city" and "mess up" the good 1 ife in the distant suburbs.50 Energy prices, 
however, are but one determinant of location decisions, as we have indicated. Even large price increases are unlikely to overwhelm countervailing considerations, at least in the short run. 51 And the incremental price effects of oil price decontrol, as we have pointed out, are not likely to be large. The Congressional Budget office puts the increase on the order of 18 of family income. And most of this impact is likely to be felt through indirect expenditures on petroleum (with little locational bias) rather than on expenditures for gasoline and home heating oil. 52

\subsubsection{Building Energy Performance Standards}

The Energy Conservation Standards for New Buildings Act of 1977 mandates the federal development and promulgation of energy performance standards for all new non-industrial. buildings. The need for federal standards is based upon congressional findings that (1) large amounts of energy are wasted in new buildings because of the lack of adequate energy conservation measures; (2) federal standards can prevent such waste; (3) the lack of adequate energy conservation features could increase operating costs and adversely affect the repayment of loans made or guaranteed by the federa]. government; and (4) state and local building codes can provide a convenient means for implementing such federal standards. The Act thus aims to assure "that reasonable energy conservation features will be incorporated into new commercial 
and residential buildings receiving federal financial assistance," through the development and enforcement of performance standards "designed to achieve the maximum practicable improvement in energy efficiency and increases in use of nondepleteable energy sources." 53 Through this Act, Congress aims to ensure results which the market has been slow or unsuccessful in producing and which past federal efforts have only partially accomplished.

The implementation of the federal standards requires action by the federal, state, and local governments. The federal government is responsible for development of the standards themselves, as well as for development of enforcement mechanisms or implementation incentives aimed at inducing states and localities to comply. States and local governments must then establish the necessary legal and organizational structures for the administration and enforcement of building energy codes equivalent to the standards or develop a separate "alternative approval" appartus by which individual buildings may be deemed in compliance.

Under the Act, the Department of Energy is to develop standards which are to be performance rather than component oriented: energy consumption goals are identified without specification of methods, materials, and processes used in achieving them. These standards are to apply to all new residential, commercial, and public buildings. 
The federal government can induce compliance with the standards using sanctions or incentives or both. States or localities not providing some method for administering and enforcing the standard are threatened with being cut off from federal financial assistance, including: (1) any form of direct loan, grant, guarantee, etc.; (2) any loan made or purchased by any bank, savings and loan institution, or similar institution subject to regulation by the Board of Governors of the Federal Reserve System, the Federal Deposit Insurance Corporation, Controller of the Currency, the Federal Home Loan Bank Board, the Federal Savings and Loan Insurance Corporation, or the National Credit Union Administration.

Incentives for implementation may be made available in the form of grants and technical assistance offered to state and local governments to aid in adoption, implementation, and enforcement of the standards. Federal tax credits may also be provided to purchasers of new buildings that comply with the standards. A public information program which informs consumers about the life cycle benefits resulting from compliance could also be used as an incentive.

State and local governments may choose between three paths for compliance with the federal standards: (1) states may adopt and administer statewide codes deemed equivalent with the federal standards to be enforced by the local jurisdictions; (2) localities may adopt and administer as well as enforce local codes certified by the states as equivalent with federal 
standards; (3) a locality or state may establish an alternate approval process enabling Iicensed design professionals to certify individual buildings.

Under the first compliance option, states must develop or update statewide codes and appropriate funds for their implementation and enforcement. They must create a new agency or designate existing agencies to handle administrative functions ranging from establishing hearing and appeals procedures and protocols for imposing sanctions, to offering localities training and technical assistance and monitoring their enforcement efforts. State officials may further have to enforce the code in jurisdictions which are unwilling or unable to do so themselves.

Localities administering equivalent local codes would be solely responsible for their adoption and implementation as well as enforcement. Local agencies and personnel would have to perform the administrative tasks required of states in the above compliance option. State officials would be responsible for certifying local codes and would act primarily in an advisory capacity. They may be called upon to monitor local. code compliance.

Compliance via an alternate approval process would require minimal administrative work for state or local governments. An agency would be designated to receive and file the certifications performed by licensed design professionals. Each consumer would be responsible under this AAP for getting 
his plans certified, and thus for absorbing the certification cost.

The anticipated effects of implementation and enforcement of the BEPS program include:

1. slight increases in earnings and employment (no significant regional differences in these differences are anticipated) 54

2. technological advances in home insulation and conservation features

3. an increase in the first costs of new residential housing 55

4. a temporary decrease in housing starts, which is expected to vary with anticipated consumer demand for housing. 56 In the long run housing starts are expected to increase slightly due to a slight decrease in housing life cycle costs

5. possibly declining emphasis on other aspects of construction (and thus guality of housing) as a result of investment of time and money in conservation features

6. financial burdens on local governments charged with implementing the standards (expected to decrease once an initial training period is completed) 57

7. increased strains on the budgets and staffs of local governing agencies charged with administering and enforcing the standards 50

8. differential impacts of increased costs by income group due to economic and attitudinal differences

The direct impacts of building energy performances on neighborhood stability are not likely to be large. The effects of the standards are in some cases only "slight" (earnings and employment); in other cases "temporary" (housing starts) and "possible" (emphasis on other aspects of construction). The direction of these effects will vary. Some effects will tend 
to make neighborhoods more stable (increases in earnings and employment, technological advances in home insulation, increases in first costs, and long run increases in housing starts); while others will tend to make neighborhoods less stable (a temporary decrease in housing starts, possible de-emphasis on other aspects of construction, financial burdens on local governments, increased strains on local government agencies, and differential impacts on income groups).

To the extent that prosperity increases the cohesion of a neighborhood and lays the groundwork for its continued survival, building energy performance standards will enhance neighborhood stability. (To the extent that prosperity leads to decreased length of residence and upgrading-by-leaving, building energy performance standards may erode neighborhood stability.) Whether the impact of increased prosperity will be to enhance or erode stability will depend to some degree on how people and governments react to the slightly greater abundance brought on by the standards. As the increase in abundance may be slight, the likely impact on neighborhood in any case will not be large.

Technological advances in home insulation and conservation features also may have a slight impact on neighborhood stability. In neighborhoods where a large percentage of the homes are in compliance with conservation standards, the values of homes are likely to be enhanced. They are likely to be less expensive to heat and cooling, and as a consequence, people's 
attachment to them and their length of residence in a community is likely to increase.

While increased earnings and employment are likely to result from the implementation of the standards, no significant regional differences in these economic opportunities are predicted. The migrations associated with regional differences in economic opportunities are thus not likely to occur. There is likely to be no net gain by cities as opposed to suburbs, or by Northeast towns as opposed to Southwest metropol ises except insofar as standards may be enforced differently in different areas and may have different "push" and "pull" effects on resident and potential residents as a consequence.

The effects of the policy on the locational decisions made by residents of a given area would likely be limited to decisions to move within metropolitan areas rather than between them. Consumers unwilling or unable to pay the added two percent costs for energy-efficient housing, for example, would likely move to areas where building energy codes are not being enforced. This type of locational decisions would be especially likely in the absence of knowledge about long-term savings in home heating bills in energy-efficient structures. Clearly, the initial choice to leave a neighborhood is not likely to be made on these grounds: this type of consumer preference results from "where to go" not "why to go" locational decisions. 
On the other hand, in some instances the decision to leave a given jurisdiction in the first place could be percipitated by differential enforcement of the standards in neighboring jurisdictions. As the costs of heating and cooling continue to rise and knowledge of operational costs in homes meeting the standards continues to spread, some consumers, especially those with large families, may well want to leave existing energy-inefficient homes. These individuals may well seek a new home in a neighboring code-enforcing jurisdiction. Their decisions will be based on the supply and demand sides of housing availability (ultimately affecting purchasing prices) as described in section 3.3 .2 .

Lower income families may be less likely to display this sort of preference in their locational decisions. Lower income groups less inclined to consider life-cycle costing in their housing cost calculations may be less willing to pay the added costs of energy-efficient homes, or they may be precluded from doing so by the practice of lending institutions. Ultimately these "equity impacts" may change the ratio between rental and ownership groups within a given area.

\subsubsection{Federal Aid for Mass Transit}

President Carter's fifth energy speech to the nation, delivered in July of 1979, encompassed a variety of proposals, 
including aid for mass transit.* In the decade of the 1980s, the President would spend $\$ 16.5$ billion for various transportation programs. The revenue would come from a "windfall profits" tax. This tax, which would be imposed on sales of domestic crude oil as price controls on old oil were lifed, originally was expected to generate $\$ 142.2$ billion in revenue during the 1980s. Recently, with higher prices of uncontrolled oil in effect, this estimation has been revised upward. The "windfall profits" tax is now likely to generate $\$ 227$ billion in revenue. ${ }^{59}$ However, the white House still recommends the same spending: $\$ 88$ billion, for a proposed energy security corporation; $\$ 24$ billion in payments to the poor to offset rising energy costs; and $\$ 16.5$ billion in aid for mass transit. 60

The administration's proposed $\$ 16.5$ billion aid for mass transit is in addition to the $\$ 27.5$ billion already committed to mass transit by the federal government and the $\$ 9.5$ billion that states and localities have to put up in matching funds. Altogether these committments would result in over $\$ 50$ billion for public transportation in the next decade for construction

\footnotetext{
*The Carter Administration, by promising to devote $\$ 16.5$ billion for mass transit, reversed its original energy policy, which excluded public transportation. President Carter made no mention of public transit when he said in April of 1977 that solving the energy crisis was "the moral equivalent of war." (Rochelle L. Stanfield, "'Windfall Profits' Tax Revenues May Be Salvation for Mass Transit," National Journal (September 22, 1979), pp. 1556-1560.)
} 
and equipment purchases. 61 operation subsidies would be extra.

The administration is planning to spend the largest portion of new mass transit funds to rehabilitate and expand existing bus and rail systems. ${ }^{62}$ It proposes to use $\$ 11.3$ billion for buses and related facilities: $\$ 5.6$ billion for modernization and $\$ 5.7$ billion for expansion. An additional $\$ 90$ million would speed completion of new rail systems under construction or planned in Atlanta, Baltimore, Buffalo, Detroit, and Miami.

There is general agreement that more buses are needed for existing systems, since 97 percent of public transit systems rely solely $\circ$ buses and 70 percent of commuters who take public transit ride buses. The national bus fleet in recent years has been deteriorating. One fourth of the national fleet is more than 15 years old. Public transit association estimates for the next four years are that old buses will have to be replaced at a rate of 4,600 a year. At the same time, more buses would be needed to meet increases in ridership. If ridership increases at a rate of 10 percent annually, nearly 5,000 new buses would be necessary. The administration's use of the windfall profits tax would double current bus production, enabling the purchase of 3,000 additional buses a year for 10 years.*

*The federal government now provides $\$ 850 \mathrm{million}$ a year in operating subsidies, but the proceeds from the windfall profits tax would go strictly for public transit capital expenditures, not for operating subsidies. 
Expanded funding for mass transit would probably influence energy consumption in two ways: it would increase bus patronage and would increase ridership on existing rail systems. 63 The administration estimates that the spending of an additional $\$ 16.5$ billion for mass transit would result in savings of 250,000 barrels of oil per day. In contrast, a proposed $\$ 2$ billion investment in residential and commercial conservation would produce savings of 500,000 barrels a day, while a $\$ 3.5$ billion investment in solar tax credits probably would save 200,000 barrels per day.

Still, there remains uncertainty about how much money will be allocated, for what purposes, and to whom. 64 policy is still in an embryonic stage. The figures that the President proposes to spend are somewhat different from the figures Congress is considering. Funds might be spent to create new mass transit systems, but there is a greater probability that they will be spent to maintain, revitalize, and expand existing systems. Funds might be earmarked for operating expenses, but there is greater possibility that they will cover capital expenditures. There may be extensive funding for experiments in use (such as more frequent scheduling, lower fares, more advertising, or more public information), or all funds might be committed to such ends as replacing old buses or purchasing new ones. Funding formulas may require one third matching contributions from state and local governments, as they have in the past, or they may only require 10 percent matching 
contributions as has been the case with highway construction. New subways systems and rail systems may be built, but it is more likely that buses and innovations such as van-pooling will be favored. The details, however, will be worked out only after the program is implemented, and funds for projects have been granted to specific communities.

In summary, the anticipated effects of increased federal aid to mass transit include:

1. a doubling of bus production 65

2. the rehabilitation and expansion of existing bus and rail systems rather than the creation of new mass transit systems 66

3. an increase in funding for experiments such as more frequent scheduling, lower fares, and more advertising

4. expansion of innovative bus services, peak only runs, for example, requiring concessions to current operators and 1 abor 67

5. Only possible increases in transit patronage. One source anticipates an increase in both patronage and ridership on existing rail systems, while another predicts no increases in transit patronage as long as income trnds make the more convenient, comfortable, automobile available to increasing numbers of people. 68 past experience has shown that patronage on new public tranport services is more apt to be drawn from existing public transportation and car pools rather than from automobiles.69 Transit improvements are likely to have an especially insignificant impact on the mode choice of upper income/suburban households. 70

6. an increase in the number of trips made.71

The impacts of additional aid to mass transit on neighborhood stability in terms of maintainence the cohesion, structure, and functioning of existing communities is likely to 
be positive. Rehabilitation and expansion of existing bus and rail systems as well as innovative experiments to improve services will strengthen stability in communities where bus and rail systems already exist. To the extent that mass transit services define and organize neighborhoods and make communities more attractive places to live, neighborhoods served by mass transit will benefit from increased aid.

However, it is more questionable whether additional aid to mass transit will draw upper income and suburban households from reliance on the private automobile as their main method of transportation; and it is also questionable whether additional aid to mass transit will reshape in any fundamental sense the character of urban neighborhoods. One source, for example, speculates that the shift towards the central city prompted by improved transit may well be offset by forces stimulating residential dispersal. ${ }^{72}$ Another source similarly notes that "the characteristics of neighborhoods such as crime rates, racial composition, and the quality of public services are...important to potential occupants and difficult to alter" and households therefore cannot be expected to respond to transportation policy changes by relocating. ${ }^{73}$

Funds committed to mass transit are likely to contribute to some changes in neighborhood composition, making particular neighborhoods more attractive places for those who are unable to drive, or who cannot afford a car, or who need supplementary forms of transportation. However, it is unlikely that 
additional expenditures, by themselves, will lead to major declines or revitilizations of urban neighborhoods, involving large turnovers and transfers in population and major changes in neighborhood stability.

Metropolitan Growth and Development

Additional aid to mass transit will not have a major impact on ongoing demographic trends, such as the changing birth rate, the relative decline in minority immigration to cities, or the increasing number of single parent families, working women, and divorcees. However, the existence of additional mass transit services is likely to be important to newcomers from abroad, who cannot immediately afford private autos, to single parent families, and to working women. These persons are likely to be more dependent on mass transit and to concentrate in areas where adequate mass transit services are available. By attracting such persons to districts where mass transit is available, federal subsidies may have some effect on the composition and stability of neighborhoods. It could make neighborhoods, where these individuals dwell, more stable than they otherwise would be.

Neighborhood Location

To what extent is the availability of additional mass transit services considered like income and employment as one of an array of opportunities available to potential migrants? 
The answer depends primarily on the need of groups for public transportation and on preferences for this mode of travel. For example, accesibility to work generally is a more important requirement for the poor. For the poor, unlike the rich, journey-to-work costs generally outweigh housing costs and force concentration in areas where public transportation is accessible. 74 To the extent that the poor are concentrated in particular neighborhoods, increased aid to mass transit will increase the stability of those neighborhoods.

\section{Neighborhood Characteristics}

Additional aid to mass transit will not affect consumer preference for low density patterns of living, for larger dwelling units, or for living in neighborhoods with various population characteristics. Nor will it affect decisions to move resulting from changes in life-stage or life-cycle. For some individuals, accessibility to mass transit is likely to be an important value. For example, some prefer commuting to work on public transportation because of the problems of rush hour traffic. Others, cannot afford or are not able to take advantage of private transportation. still others, of necessity, must supplement their reliance on private transportation with the use of public transportation. For these individuals, improved transit service resulting from additional federal expenditures will continue to play an important role in their locational decisions. It will attract 
them to neighborhoods that provide improved service and may increase the cohesion of these communities.

\section{Individual and Household Decisions}

Will more spending for mass transit cause people to move to core-city areas? Lave summarizes his view of the empirical evidence: good public transportation is not likely to attract people out of cars; it is not likely to decrease private automobile ownership; and it is not likely to change the proportion of people dwelling in cities and surburban areas. ${ }^{75}$

Lipton's findings suggest that substantial in-migration of younger higher status people to particular urban neighborhoods already has taken place. ${ }^{76}$ The impact of increased federal aid to mass transit on neighborhood stability is likely to depend critically on the value a young, well educated, professional group attaches to public transportation. To this group, it may become a factor which has to be considered along with other factors when making household location decisions.

\section{External Organizations}

If funding formulas restrict aid to mass transit obligations to capital expenditures, these restrictive practices may partially contribute to decreasing revenues, which will contribute to an exodus of people from urban areas. In addition, if construction of new mass transit puts a strain on municipal resources because of federal matching grants 
requirements, this strain on municipal finances also will contribute to an exodus of people. People remaining are likely to be those who must rely on public transportation and who have no recourse but to stay and to pay higher taxes. It is well known that the rising tax burden in urban areas already is shouldered more by inner city residents despite incomes which are substantially lower than those of suburbanites. If there is a strain on municipal finances because of additional aid to mass transit the impact on neighborhood stability is likely to be regative.

On the whole, the effect of increased aid to mass transit on neighborhood stability will be to slow down to a small extent the trend of continuing surbanization and migration to "sun belt" cities. But there are fundamental factors driving this trend forward, which aid to mass transit cannot address. These factors are not likely to be affected by a redirection of resources from highways and automobiles to mass transit. 



\subsection{HOUS ING AVAILABILITY}

\subsection{DEFINITION AND MEASURE}

Housing availability connotes more than the number of dwelling units available for habitation. To an individual searching for a place to live in a commurity, housing availability depends on his ability to pay for housing and the prices at which housing is available. The greater the ability to pay or the lower the prices, the more available is the housing. The lesser the ability to pay or the higher the prices, the less available is the housing. Thus we define housing ability as the price of available housing relative to buyers' ability to pay.

The individual's ability to pay, in turn, depends primarily on income, prices of other goods and services, and the "need" for housing (e.g., as a result of family size). Housing prices, on the other hand, depend primarily on demand (the amount of housing that buyers will purchase at various prices) and supply (the quantity of housing offered for sale at different prices). Housing prices, in short, result from the economist's familiar competitive equilibrium where price of the commodity is such that quantity demanded just equals quantity supplied.

In the aggregate, the equilibrium price itself is in part determined by demand, a major component of which is ability to pay. We therefore will view ability to pay as a determinant of 
price. For the purpose of measuring housing availability, we will assume that ability to pay is constant. As price declines (ability to pay remaining constant), individuals will find it easier to purchase housing. As price increases (ability to pay remaining constant), individuals will find it more difficult to do so. Thus our measure of housing availability (housing prices) is more restrictive than our definition of housing availability (housing prices relative to ability to pay). This restriction is necessary to keep the analysis workable.

Our notion of price includes down payment, real estate taxes, * repair, maintenance, and utility costs, ** opportunity costs, and the cost and availability of credit. I Price is what allows housing to pass from sellers to buyers or from owners to renters; but it is not necessarily the same as offered price, as offered price does not always clear the market. The notion of price implies that what is offered is bought. 2

Of course, this view of housing availability is highly simplified. It corresponds to the assertion that the housing

\footnotetext{
* At about two to three percent the market value of $l$ and and structure, real estate taxes are equivalent to a 25 percent sales tax.4 Mills writes, "(the) only commodity taxed at similar rates are cigarettes. . whose consumption society clearly wishes to discourage as a matter of public policy." 5

**The fact that as energy prices go up, standard household utilities become more expensive, increasing the cost of housing and making it less available, is a point which we will discuss later.
} 
market in a community can be treated as competitive--in short, that it satisfies the following assumptions: ${ }^{3}$

- That there are many housing units for sale and that many people are looking to purchase these housing units;

- That many units are bought and sold and that there is no collusion among buyers or sellers;

- That no single sale affects market price;

- That people can become buyers and sellers almost at will;

- That buyers are aware of what is being offered at different prices and sellers are aware of what is being sold at different prices;

- That both buyers and sellers are trying to maximize gain;

- That there are no artificial restrictions on what can be offered for sale or what can be bought; and

That what is bought and sold is a "homogeneous
commodity." 6

That housing is a "homogeneous commodity" is the most controversial of these assumptions. ${ }^{7}$ The housing units themselves may be detached, semi-detached, or part of multiple-dwelling units. ${ }^{8}$ They may vary according to square feet, number of rooms, and desirability of location. ${ }^{9}$ Housing services may be purchased or rented; * they may be obtained for use, investment, or both.10 And the price of

*Most people in the United States (over 60 percent) own their homes. II 
housing may be different for different social groups. For example, it has been argued that "the price for an equal amount of housing service is higher for blacks than for whites" and that this situation is maintained through "collusive behavior and high level of market organization." 12

These differences among housing units and among housing buyers leads some to argue that housing should be divided into different submarkets. ${ }^{13}$ However, for purposes of urban and community impact analyses, there is probably no workable alternative to an aggregate approach such as that adopted here, which is admittedly crude and oversimplified. Moreover, there is a rich literature in the aggregate analysis of urban housing and $l$ and use which can be drawn upon for help. Three broad approaches have proven useful. One focuses directly on the statistical analysis of the relationships between income, family size, race, and other social and demographic variables, and the demand for housing. ${ }^{14}$ A second strand of anlaysis, closely related to the first, is more directly interested in the analysis and prediction of changes in housing supply; specifically investment in new housing. ${ }^{15}$ A third area makes use of simplified, two-dimensional theories of location and urban land use to analyze changes in location patterns in response to urban growth, changes in the transportation system, racial segregation, changes in income and changes in preferences for urban location. ${ }^{16}$ we draw on all three approaches, especially the first two, in the discussion of determinants. 


\subsection{DETERMINANTS}

Housing prices are determined by demand and supply. Demand reflects the quantity of housing buyers are willing and able to purchase at different price levels. As illustrated in Figure 3.1, the typical demand curve DD slopes downward to the right. This is because people are able and willing to pay for more housing at lower prices than they are at higher prices. At price $P$ buyers will purchase only $Q$ quantity of housing. If the price dropped to $\mathrm{P}^{\prime}$, they would purchase the greater quantity of $Q^{\prime}$. Thus as one moves to the right along a typical demand curve, prices fall. As a result of factors such as income, prices of other goods and services, and need, demand as a whole may also increase or decrease: that is, for any given price, the quantity of housing demanded may increase or decrease. An increase in housing demand is illustrated by a shift to the new demand curve $D_{1} D_{1}$. Now, at price $P$, buyers would purchase quantity $Q_{1}$ of housing, instead of just $Q$ as before. Similarly, they would purchase more housing at any given price than they would when demand was only at the level corresponding to the old demand curve DD.

A similar analysis applies to housing supply. Supply reflects the quantity of housing that will be made available at various prices. As illustrated in Figure 3.2, the typical 


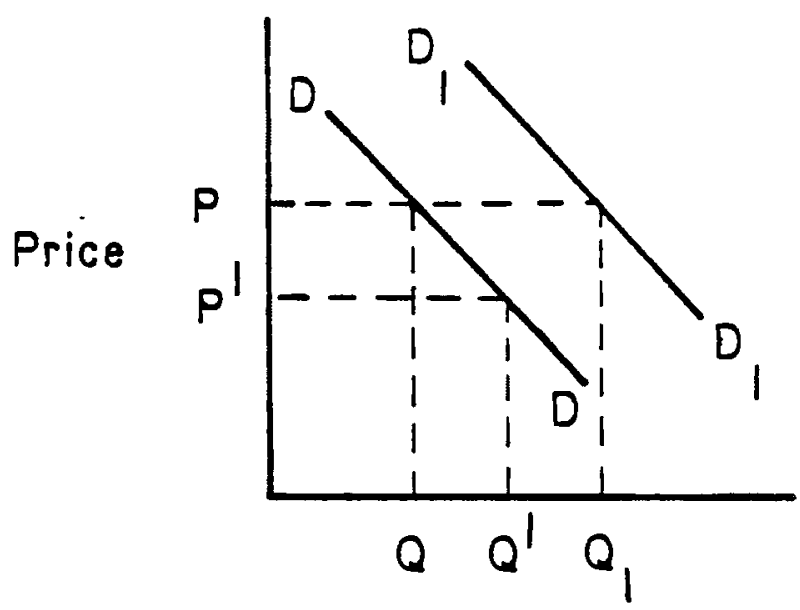

Quantity

FIGURE 3.1. Demand for Housing

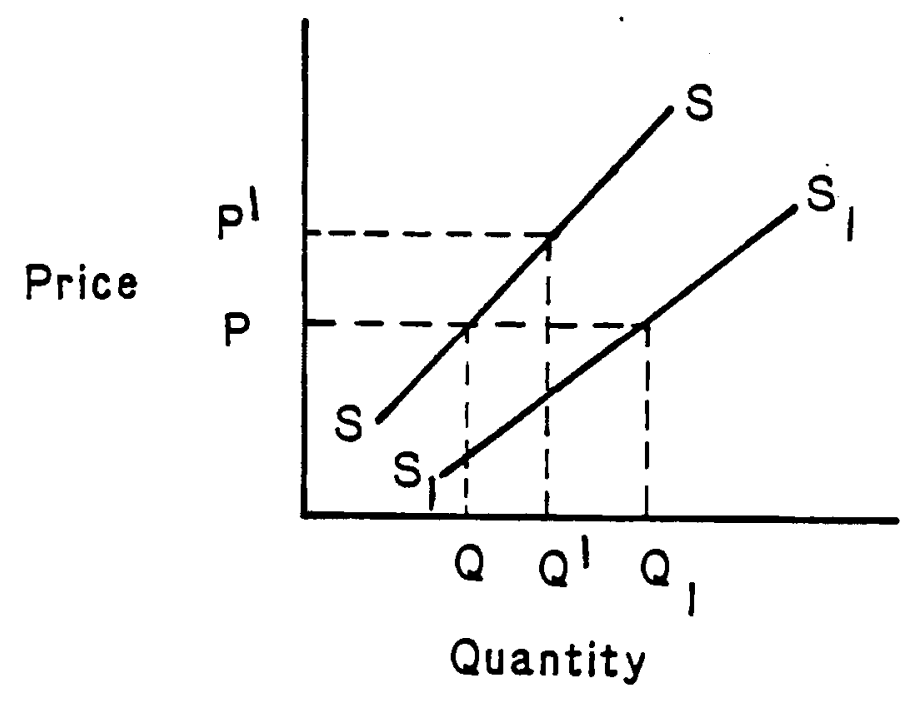

FIGURE 3.2. Supply of Housing 
supply curve SS slopes upward to the right. This is because people are willing to make available more housing at higher prices than they are at lower prices. At price P, people will make available only $Q$ quantity of housing services. At the higher price of $\mathrm{p}^{\prime}$, however, people would make available the greater quantity of $Q^{\prime}$. Thus as one moves to the right along a typical supply curve, prices rise. As a result of the factors discussed in section 3.2.2, the overall supply for housing may increase or decrease: that is, for any given price the quantity of housing supplied may increase or decrease. An increase in housing supply is illustrated by the new supply surve $S_{1} S_{1}$. Now at price $P$, suppliers would make available the quantity $Q_{1}$ of housing, instead of just $Q$ as before. Similarly, they would make available more housing at any given price than they would when supply was only at the level corresponding to supply curve ss.

Now consider the effects of demand and supply together, as illustrated in Figure 3.3. At a point in time demand DD and supply ss will result in $Q$ quantity of housing clearing the market at price $P$, which is the price at which the quantity of housing demanded just equals that supplied. Now suppose demand increases, for example because of a sudden influx of new workers to the community. Such an increase in demand is indicated by the shift to the new demand curve $D_{1} D_{1}$ in Figure 3.4. In the short $r$ un, the supply of housing cannot be increased through new construction, so the supply curve cannot 


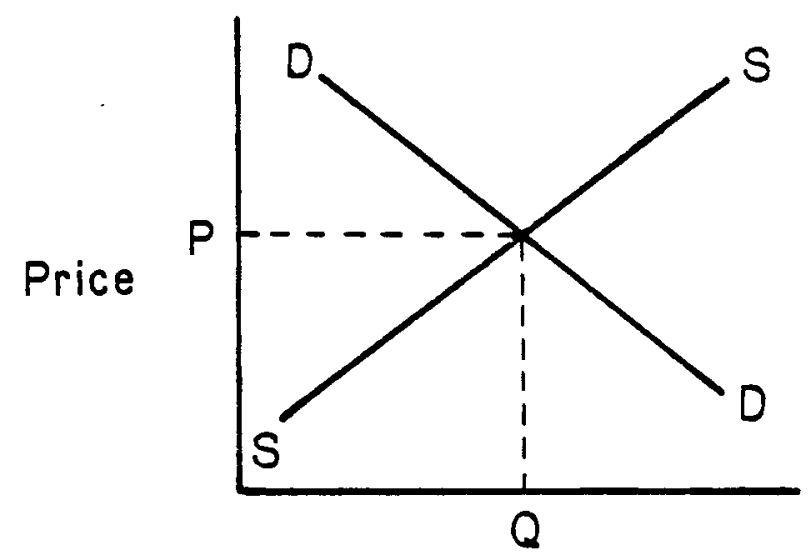

Quantity

FIGURE 3.3. Equilibrium Price of Housing

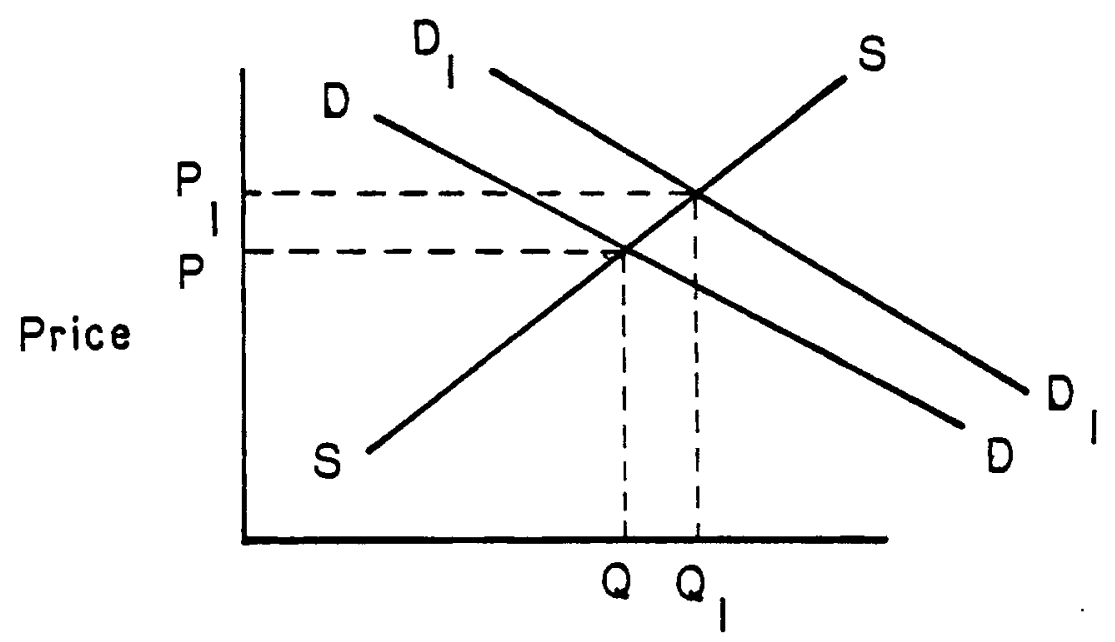

Quantity

FIGURE 3.4. Short Run Results of Increased Demand for Housing 
shift. However, some existing housing that was unavailable at the old price $P$ may be made available at higher prices. In other words, movements along the existing supply curve are possible. The result is the new equilibrium at $P_{1} Q$, where the new demand curve $D_{I} D_{1}$ intersects the original supply curve ss: a greater quantity of housing will be supplied $\left(Q_{1}\right)$, but a greater price $\left(P_{1}\right)$.

In the long run, the increased demand is Iikely to stimulate new construction, resulting in a rightward shift of the supply curve to become $S_{1} S_{1}$ as illustrated in Figure 3.5. The new equilibrium is at $P^{\prime} Q^{\prime}$ where the quantity of housing sold is $Q^{\prime}$ (greater than both the short run equilibrium quantity $Q_{1}$ and the original equilibrium quantity $Q$ ) at the

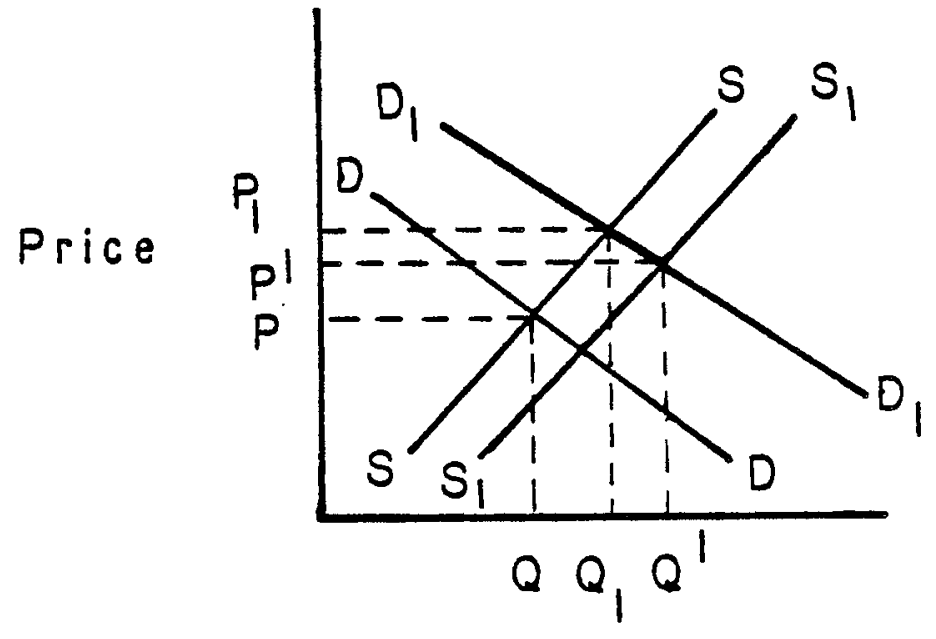

Quantity

FIGURE 3.5. Long Run Adjustment to Increased Demand 
price $P^{\prime}$ (less than the short run equilibrium price $P_{1}$, but still greater than the original price P). This long run result--increased demand stimulating increased supply resulting in additional housing at higher prices--is the expected one for an increasing cost industry, which is probably the case for the housing industry in most communities. Because land is ordinarily in fixed supply, the cost of providing housing increases as supply increases, with the result that the new equilibrium price is higher than the original price. (If housing were a constant cost industry, the price would be the same at the new long term equilibrium as it was originally.) This very simple model serves to predict the impacts of changes in supply and demand on housing prices and thus housing availability. In turn, supply and demand are determined by a variety of factors.

\subsubsection{Demand}

Principal determinants of demand for housing include the following:

- Consumer income and assets

- Cost of other goods and services

- Expected after-tax return on investment relative to alternatives

- Consumer preference for housing relative to other goods and services

- Mortgage guarantees and income tax deductions 
- Population growth

- Number of households

- Employment opportunities

- Cost and availability of transportation

- Amenities

- Social conflict (disamenities)

Percentage of disposable income available for housing will influence the number of people seeking the commodity. Percentage of income spent on housing is an indicator of affordability. Among housing experts there is controversy about whether housing is becoming more or less affordable. It is believed that the proportion of income a family must spend on housing has been increasing for large segments of the population, especially for low income families.17(In 1970 , for example, the ratio of home price to owner's income was around 1.7 to $1 ;$ in 1980 , it was approximately 2.3 or 2.4 to 1. 18 But the quality of housing in terms of soundness of structure or presence of adequate plumbing facilities also may be improving. 19 In addition, it has been pointed out that more people view housing not as a simple commodity, like food and clothing (which is consumed and discarded), but as a investment, like precious goods (gold, diamonds, or art) that are kept for their potential long term earnings. 20 People are likely to spend a larger proportion of their income on housing when there is an especially inflationary situation in the housing market and the promise of large future returns. 
In fact, the rate of inflation for housing usually exceeds the rate of inflation for other goods and services. Mills, for example, reports that during the first half of the twentieth century, "housing prices rose about twice as fast as average consumer prices."2l A trend of this nature was significant in the 1970s. It may partially explain consumer preference for housing relative to other goods. However, there are other explanations. For example, a large family may need to consume more housing than a small one. Such family size or life-stage considerations will affect consumer preference for housing. The size of the house, kind, sizes, and arrangement of the rooms, condition of the materials in the structure, and style and decoration also will affect consumer preference. ${ }^{22}$ Anti-inflationary policies that result in higher interest rates increase the cost of owning a home, lead to higher rents in the rental market, and reduce the market for new housing. Federal Home Administration and Veterans Administration mortgage guarantees partially compensate for these policies by increasing the availability of credit, especially for low income lenders who cannot secure loans otherwise. ${ }^{23}$ In addition, income tax deductions on home mortgage interest and real estate taxes increase housing demand but mostly for high income residents because "a higher income means a higher marginal tax bracket and greater tax breaks for owner occupancy." 24 
Residential mobility, as it places more people in the housing market, also may stimulate the demand for housing. The reasons for residential mobility are complex. ${ }^{25}$ Among the factors frequently mentioned are the following: population growth, changes in transportation and employment opportunities, the attraction of particular amenities, the existence of social conflict, and so on.

According to Banfield, an expanding birthrate propels expansion of the city outward into outlying districts and less populated cities and towns. ${ }^{26}$ Expansion of the population to outlying areas is by now a common phenomenon. In the early 1970s, at least 10 of the nation's older metropolitan areas were losing population. 27 New areas were gaining potential homeowners. Housing specialists predict that in the 1980 s 16 to 17.5 million new households will be formed, primarily because children of the "baby boom" will reach home-owning age (i.e., 30). 28 In the 1980s, forty-two million people will reach their prime home-buying years, as compared with 32 million in the 1970 's. ${ }^{29}$ Along with reductions in the size of the average household (from 3.2 people in 1970 to a predicted 2.5 in 1990), population growth will increase the demand for housing. 30

When deciding where to live people generally consider accessibility to place of work as an important factor. Housing that is accessible to places of employment is more likely to 
command a premium price in the market. 31 Also, it is now generally believed that intermetropolitan differences in economic conditions-rapid growth of employment and high income-play an important role in determining flow of migration. 32

The number of consumers that migrate to a particular area is affected by their attraction for particular amenities. For example, people may prefer the climate and life-style of the Sunbelt to that of the Northeast. Migrants will move "toward areas with warm weather" and "away from polluted areas."33 Extreme climates--very hot in summer or very cold in winter--will discourage people from moving to an area and encourage them to move from the area. 34 Large cities, on the other hand, are likely to attract people and businesses because of their "diversity."35 A large city usually offers a greater variety of shops, museums, theaters, restaurants, neighborhoods, and housing. 36 Diversity generally acts as a magnet for "higher income, young households without children." 37

Pulling in the opposite direction of diversity is social conflict. In the spring of 1975, James Coleman released the "preliminary results" of a study concluding that school desegregation contributed to "white flight" from big cities 38 Diane Ravitch concludes an assessment of this study by saying: 
It seems unlikely that we will ever know with any degree of certainty whether whites (and some middie class Blacks) are leaving the city because of concern about desegregation or crime or poor services or racial tensions or the quality of life or for some other reason or combination of reasons. But if it is impossible to measure the precise impact of school desegregation on "white flight," it is equally unsupportable to claim that there is no effect whatever. Court ordered busing may or may not be the primary stimulus of white withdrawal from the city schools, but it is very likely a contributing factor.... 39

\section{2 .2 Supply}

Housing is offered for sale when new units are constructed. However, housing is a durable asset that typically lasts 50 years or longer. 40 New construction therefore usually provides less than 5 percent of the housing that is offered for sale in a given year. 41 More commonly, housing is offered for sale when people move. Given that the average family moves once in five years, it is estimated that 20 percent of the housing stock in the U.S. is on the market each year. 42

Principal determinants of the supply of housing in a community include the following:

- Construction costs (e.g. cost of materials, electrical work, plumbing, etc.)

- Cost and availability of land (and accessibility through the transportation system)

- Cost and availability of credit 43

- Expected after-tax return on investment relative to alternatiaves

- Rent controls

- Building codes 
- Depreciation allowances

- Land use controls

- Characteristics of the housing industry

- Energy and environmental controls

- Union practices

Thus, the supply of housing depends partly on factors affecting the construction industry and the business sector generally.

But supply also depends on factors that mostly originate with government. Rent controls, for example, tend to decrease housing supply. 44 They lead to a "low rate of construction of new housing and reduced maintenance of old."45 Building codes also tend to decrease availability by raising prices and making builders more reluctant to start new projects. 46 Accelerated depreciation tax allowances may decrease supply by encouraging rapid turnover in rental ownership. Zoning ordinances also may decrease supply particularly for low income people. 47 (Some communities require large minimum lot sizes, which raise prices and tend to exclude minorities.) Energy and environmental controls may also play an important role in determining the supply of housing. According to Frieden, environmental regulations discourage new construction, raise housing costs and exclude non-wealthy people from housing without producing "important environmental benefits for the 
public at large." 48 siedel holds that the overall effect of growth restrictions and other government measures such as energy conservation and environmental controls is to raise construction costs by imposing unnecessary delays. 49 seidel found that delays could be "serious," up to 12 to 24 months for review by a municipality under traditional codes (building, subdivision, and zoning) and newer ones (energy and environment). Dowall also has found that environmental controls negatively affect housing supply. 50 Government controls, according to Dowall, predispose developers to orient their projects to high income groups onto which they more easily pass their costs.

Finally, the structure of the housing industry itself may effect housing supply. Important characteristics of the housing industry are that:

- most firms which construct dwelling units are small;

- many tasks are subcontracted to other firms rather than performed by a general contractor;

- building is fragmented into numerous subtasks, performed by different specialists (plumbers, landscapers, etc.); and

- production is localized because each home site is somewhat unique and it is expensive to ship components over large distances.

As a result of these features, the housing industry is very competitive. But according to some, it shows an inability to 
innovate. 51 Part of the explanation may be union practices. 52 Charges about "archaic union practices" generally are that: (1) rules that certain work only be performed at the construction site; (2) restrictions against using particular methods and devices; and (3) excessive health and safety requirements. ${ }^{53}$ These factors may increase the cost of labor and thereby also decrease supply.

\section{2 .3 Summary}

The principal determinants of housing availability are summarized in Figure 3.6. Overall, housing availability--defined as housing prices in a community--is determined by the demand for housing relative to its supply. In turn, demand and supply are each determined by a variety of factors, portrayed as bulleted items. In the short $r$ un, demand and supply interact, but demand does not affect supply. In the long run, demand is itself one determinant of supply.

\subsection{IMPACT OF FEDERAL ENERGY POLICIES}

The three illustrative energy policies act in differing fashions to affect housing availability. Oil price decontrol affects many of the determinants of both demand and supply, though only slightly; BEPS acts primarily through the supply side, and may result in fairly significant impacts; federal aid to mass transit affects almost exclusively the demand for housing, though the magnitude of the impact is difficult to estimate. 


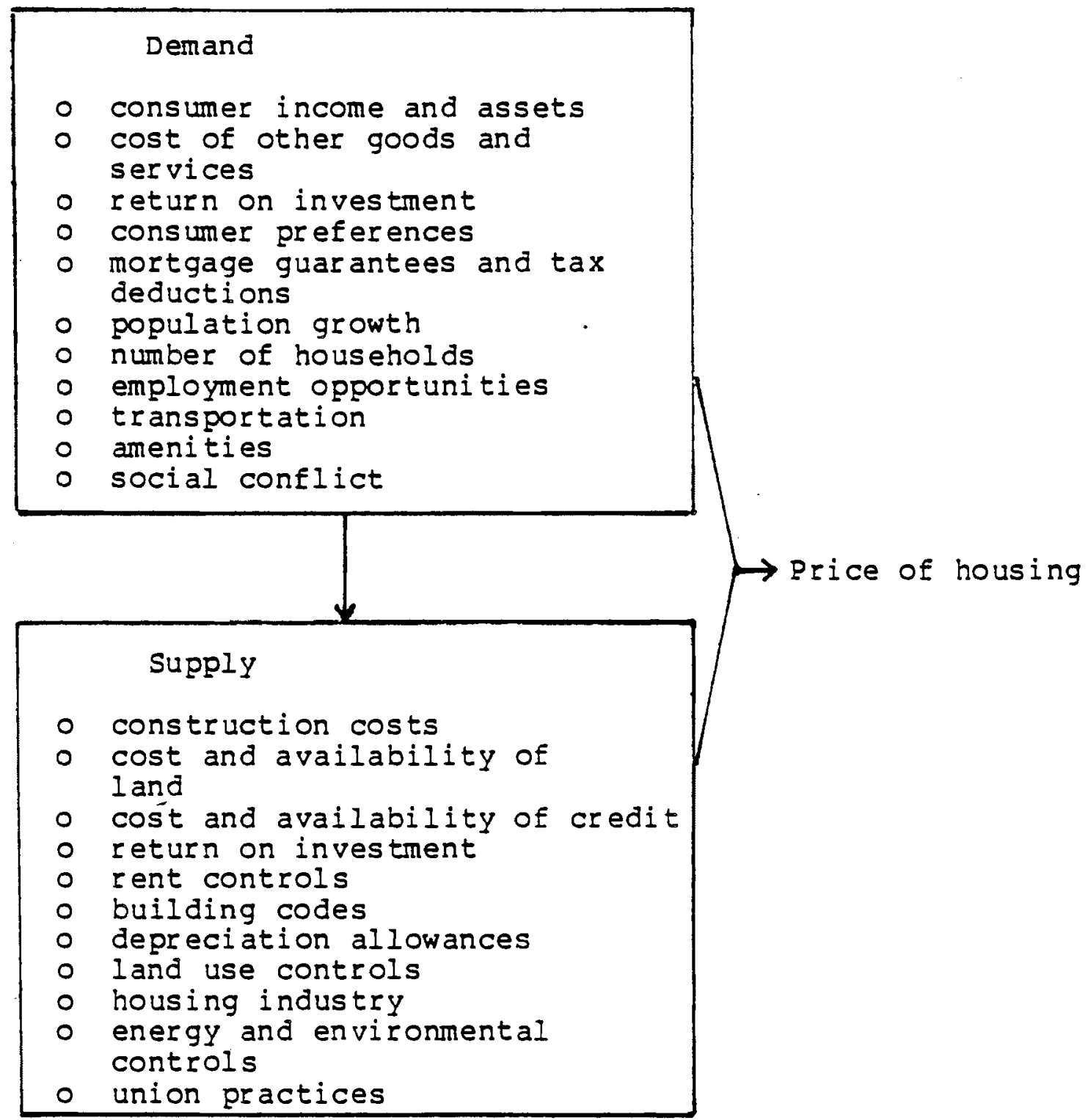

FIGURE 3.6. Determinants of Housing Availability 


\subsubsection{Oil Price Decontrol}

An increase in the price of oil to world levels will raise the price of housing for people who depend on heating oil and petroleum generated electricity. The direct impact is important but at first glance not major because it is restricted to a particular category of users located to a large extent in particular regions. Also it can be overcome to the extent that people conserve or switch to alternative fuels and to the extent that utilities change the way they generate electricity.

In regions of the country where oil is a major source of home heating and electrical generation, price decontrol may increase the demand for more energy efficient housing--for example, smaller houses, cluster housing, multifamily housing, and new housing that incorporates energy saving measures. Decontrol also could exert upward pressures on existing apartment rents and condominium and small house prices. It thereby, in the long $r$ un, could increase the supply of new, more energy efficient housing. Similarly, if the demand for larger, detached single family housing was reduced, the price of such housing in the long $r$ un would fall. Houses that are "oil guzzlers" not unlike the automobiles that have been labled "gas guzzlers" would be considered too expensive to own or dwell-in.

These are likely direct impacts of oil price decontrol on housing availability. Indirect impacts, however, may also occur. Although we are not in a position to quantify impacts, either direct or indirect, we can in a general way specify the direction of change that price decontrol brings about. 
Caveats, of course, apply. As we have shown, energy prices are but one factor influencing housing availability. Demographic forces, interest rates, and deeply rooted preferences for particular types of housing could well dominate. Moreover, the magnitude of the impact of oil price decontrol on housing availability is likely to be quite small. The following discussion is intended to illustrate how the causasl model can be applied to a particular policy. It should not imply that oil price decontrol will have very significant impacts on housing availability.

\section{Impacts on Demand}

Decline in economic output, increased unemployment, and decline in real income will marginally affect consumer income and assets (unless the consumer happens to be employed in the petroleum industry, owns substantial petroleum company stocks, or is involved in the production of substitute products and services). A marginal decline in income and assets will decrease housing availability for most individuals but will have a particularly adverse effect on low income families and on families that consume more gasoline, such as those in far-away suburbs and isolated rural areas. 54

An increase in inflation will mean higher prices for goods and services, in particular higher prices for goods and services which require relatively large transportation inputs or depend on the availability of petroleum by-products for feedstock (such as chemical and pharmaceutical products). Consumers will thus have less disposable income for housing. They will be less able to purchase the commodity. 
Increased prices, decreased employment, and poor economic conditions are unlikely to affect consumer preference for housing relative to other goods and services. However, a tendency toward increased preference for smaller, more energy-efficient homes is likely to be manifested by some individuals.

It is unclear what effect oil price decontrol will have on expected after-tax returns on investments in housing. Based on past occurrence, it is likely that housing will hold its own or do better in comparison with other investments, even after oil prices reach world market levels. Housing prices are likely to rise faster than the general rate of inflation and to be perceived by most people (next to investing in a commodity like gold) as an excellent way to reap long-term income.

The increased inflation and unemployment and decline in economic conditions that would accompany a rise in oil prices would put additional pressure on the government to provide services such as guaranteed mortgages to home buyers who could not otherwise secure a loan. It would likely lead people with the wealth to afford a high-level of gasoline consumption to seek real-estate investments in order to gain tax write-offs. High income people would be more likely to to rely on housing as a hedge against inflation.

Oil price decontrol will have no discernible effect on number of households. It may make it more difficult for immigrants to come to America and establish themselves but "baby boom" pressures on the housing market are likely to 
persist even after increases in oil prices. Higher prices may delay in many cases the decision to buy a home or to rent an apartment, but only when that decision is delayable. 55 Generally, it will take people longer to save the money to place a down payment on a home; or it may drive people to place smaller down payments than they normally would and to bear larger monthly payments, thus further reducing their disposable income.

The impact of decontrol will be to push people from locations where industry depends to a greater extent on petroleum to locations where there is less dependence on oil. Areas that produce oil substitutes (shale, coal, solar, nuclear power, etc.) may attract large numbers of new households. The housing markets in regions of "new energy" development are likely to experience increased demand. However, increased demand may not mean less availability, as people who move because of job opportunities will probably be receiving higher incomes.

Housing that is close to people's shopping and place of employment will be more in demand after price decontrol, while housing that is far from shopping and place of employment will be less in demand.56 People will find it harder to live near the particular amenities--whether they be forests and scenic areas or the excitement of big cities--if these amenities are distant from their place of work and shopping. Finally, after oil prices rise, those fleeing large cities because of social 
turmoil will have to balance increased costs of transportation against the perceived benefits.

\section{Impact on supply}

By adding to construction costs (costs of materials, electrical wiring, plumbing, etc.), increases in oil price decrease supply. They make land in areas centrally located less available and increase the cost, but make land in distant areas more available and less expensive. Land, near to where alternative energy sources are found and can be developed, is likely to increase in value; while land far from these energy sources and places of development is likely to decline. Credit will be tighter and the cost of credit is likely to increase as higher oil prices put additional pressure on the rate of inflation, and the goverment feels compelled to adopt tighter monetary and fiscal policies to combat this condition.

Expected after tax return on investment in housing relative to the alternatives, given past historical examples, is likely to remain the same or to increase. Therefore, housing is likely to continue to be perceived as a good investment, if in some ways also a riskier one. New construction is likely to be streamlined and housing is likely to be produced in a more energy-efficient manner, especially as institutional relations remain difficult and delays are Erequent. 
Because of additional unemployment and a decline in real income, there may be pressure to establish rent control. where none presently exists or to tighten controls where they already govern. This is likely to decrease the number of renta? units available and to lead to a decline in the quality of ones already in existence. Conversion from rental units to condominiums, a trend that began in the late 1960s is likely to be accelerated. In order to increase the number of rental units available, the government may be compelled to offer landlords other tax advantages besides depreciation allowances or to liberalize further the latter benefit.

As a result of increased oil prices there could be pressure to loosen building codes so as to lower housing costs. 57 Increased oil prices and a general decline in economic conditions (including higher construction costs) may have a marginal impact on the inefficient aspects of the construction industry. Given adverse economic conditions, only competitive firms with innovative practices are likely to survive or prosper after price decontrol. These firms may be larger and more integrated than the firms of the past; but it is also possible that they will be smaller, more specialized, more flexible, and more mobile.

The housing industry already has voiced its opposition to energy and environmental controls that add to construction costs. 58 If these costs cannot be reduced or the controls loosened, the industry is likely to orient its production more 
toward the wealthy and less toward the poor. ${ }^{59}$ The poor may be priced out of the market because of the additional government requirements.

Finally, after decontrol the construction industry may be less tolerant of union practices that contribute to inefficiency. As union demands increase to compensate for increased inflation, high unemployment, and decline in real income, builder demands for lower wages and benefits and increased productivity will also increase. Labor strife in the housing industry could intensify, leading to more delays, higher costs of construction, and less housing available for sale.

Overall, the impact of oil price decontrol on the housing market will be to decrease availability. This is the case particularly in the short run. As previously indicated, oil price decontrol will result in increased prices for home heating oil, for petroleum generated electricity, and also for gasoline, and products that use petroleum in their manufacture. Increased prices are likely to increase the demand for housing in urban areas accessible to alternative means of energy and in possession of well-developed transportation networks. To the extent that there is land available for urban development, the supply of housing increase in the long run may increase. To the extent that urban areas are fully developed, the result could be to bid up the price of housing. Similarly, increased gasoline prices could reduce the 
demand for suburban and rural housing and thus exert some downward pressure on prices. But again this is likely to be a long term trend.

\subsubsection{Building Energy Performance Standards (BEPS)}

The Building Energy Performance Standards program wil 1 affect the supply and demand relationships determining housing availability primarily through its effects on the costs of new housing and secondarily through its effects on consumer income and preference. Current predictions indicate that buildings constructed to meet the standards will cost, on average, two percent more than they would without the additional thermal efficiency features. ${ }^{60}$ The effects of higher building costs will vary, however, depending on how many jurisdictions within a given area comply with the conservation standards and the means used by the federal government to induce compliance. The effects on supply and demand may further be differentiated for different groups of people. These differential effects are the result of economic and attitudinal differences among residents and the practices of lending institutions. These "equity impacts" will again further depend on the implementation strategy chosen by the federal government.

\section{Impact on Demand}

Demand for housing may increase with expected increases in earnings and employment. While these increases are slight, 
they are expected to be consistent nationwide. Increased demand for housing, as is generally predicted by economists under such circumstances, is likely accompany income and earning increases.

Changes in demand will depend on "the perceived value consumers place on improved housing efficiency," or to put it differently, on "whether first costs or life-cycle costs are more relevant to the consumer's decision making process." 61 Consumers will weigh increased construction costs against the benefits of reduced energy bills. By their decisions, they will partially determine the price of energy efficient new housing and the price of older housing not meeting the energy efficiency standards. ${ }^{62}$

A study prepared for DOE concludes that in areas in which all new buildings were to meet the standards (areas of 100 percent compliance), ${ }^{63}$ the two percent average increase in housing costs would not be paid by the average consumer in the short run. "The price of houses that complied with the standards would have to be slightly discounted in order to sell."64 It is further noted that the older houses not meeting the standards would become slightly more expensive as a result of consumers' unwillingness to pay the full additional costs of houses designed with the conservation features. In the long $r$ un, however, it is predicted that new housing would increase in price by the full two percent as demand increased 
with consumer awareness of the true value of buildings meeting the standards. 65

The DOE report also cites evidence which suggests that "lower income groups are less inclined to perceive life-cycle savings from energy consuming improvements because of the heavy discount placed on future income." The rate of discount is "the rate at which (individuals) would be willing to trade present income for future income." 66 Thus, especially in jurisdictions with high total compliance rates, the demand for housing amongst lower income groups is likely to be less.

The DOE report also notes that while some consumers consider life-cycle costing in their calculations of overall housing costs, it is not yet clear whether lending institutions similarly consider life-cycle costs in making decisions on loans and mortgages. If these institutions remain with current practices, ignoring decreases in life-cycle costs from the energy-efficient designs, individuals in with lower incomes, typically having less favorable credit ratings, are likely to be differentially priced out of the housing market. Once again, demand for old housing may rise as a result, as will its price.

\section{Impact on supply}

The Building Energy Performance Standards program will affect the supply of housing primarily through its effects on housing starts. These effects in turn will be determined by 
expected demand as well as by the implementation strategies chosen by the federal government. Effects on the quality side of housing supply may result if there is declining emphasis on other aspects of construction as a result of increased investment (time and money) in conservation features.

Based on calculations of the price elasticity of the demand for houses, a two percent increase in housing construction costs would result in 1.8 to 2.8 percent fewer housing starts. This decrease is seen as "a reasonable upper bound of the impact." 67 Consumers willing to pay the additional cost for energy efficiency features were distinguished from those not willing to pay this extra amount. On average, consumers willing to pay the added costs perceive a roughly one percent increase (rather than a full two percent) in construction costs of houses which complied with the conservation standards. A perception of one percent increase in housing costs would lead to only a .9 to 1.4 percent decrease in housing starts. In other words, where consumers were willing to pay the added costs, decreases in housing starts would be less than .9 to 1.4 percent, but where consumers were unwilling to pay the added energy efficiency costs, housing starts would decrease by less than 1.8 to 2.8 percent.

The lower the compliance rate within a given area, the smaller the decrease in housing starts is likely to be. In areas with 100 percent compliance, supply of new homes could 
well outstrip demand in the short run, though supply of older buildings.would fall short of demand. In the long $r$ un, however, demand and price for new homes would increase as supply diminished.

In areas in which consumers could choose among new homes not meeting the standards, new homes which do, and older non-efficient homes, the effects on housing costs might be different than the case of 100 percent compliance. The actual number of non-complying dwelling units would be pivotal. The DOE report suggests that with a twenty percent compliance rate, no decrease in housing starts would be expected. 68

The quality side of the supply of housing also may be affected by implementation and enforcement of BEPS. As more and more emphasis is placed on constructing homes to meet energy-efficient designs, the quality of other features of the structure may be sacrificed. Builders may try to cut corners on some aspects of construction in an effort to compensate for the higher costs of the energy-efficient requirements. Furthermore, in some cases in which building energy codes have been put into affect, conflicts between these codes and other aspects of building codes may arise.

\subsubsection{Federal Aid to Mass Transit}

Additional government aid to mass transit will increase accessibility to employment, recreation, and shopping for some people. These people are likely to be those who cannot afford 
a car, those who are not able to drive, and those who prefer buses and subways to private autos as their main form of transportation. These groups, which have greater need for mass transit are primarily the elderly, the poor, adolescents, working women, those who prefer living in big cities and others. At the least, federal aid to mass transit is likely to bring about an upward movement in the value of housing available to these individuals Two other impacts of increased federal subsidies are worth noting. To the extent that people's locational decisions are based on improved mass transit services, federal subsidies to mass transit will increase demand for housing in parts of the city served more adequately by the provision of these services. There also may be some increased demand for housing associated with the employment opportunities created by the construction of new transit systems, production of buses and the addition of personnel who drive and maintain buses and subways, plan schedules, and do advertising or public relations.

A doubling of bus production will increase consumer income and assets in areas where the production takes place. Rehabilitation and expansion of existing systems will have the same effect. The economic impact of increased aid to mass transit generally will be to stimulate neighborhood economies. specific economic impacts are summarized in a recent article by Davis. 69 Additional aid to mass transit "provides greatest economic gains in central portions of a city, in its high 
intensity activity area, and in the immediate vicinity of station areas."70 It causes "residential and commerical activities to cluster in the station areas." 71

The impacts of increased aid to mass transit on housing availability are generally demand related. Federal aid to mass transit does not impact the quantity of housing supplied. Movements in the monetary sector, for example, have little relation to aid to mass transit. Important characteristics of the housing industry, also, are not affected. There is some effect, however, on the cost and availability of land, as public transit systems must obtain rights of way.

Nonetheless, the overall impact of increased aid to mass transit is to improve the lot of particular segments of the public who rely more heavily on it. 
.

. 


\subsection{QUALITY AND AVAILABILITY OF PUBLIC SERVICES}

\subsection{DEFINITION AND MEASURE}

Specifying a useful definition and measure for "quality and availability of public services" poses obvious difficulties. Quality is plainly a matter of subjective evaluation-because of differing preferences people routinely disagree as to the relative quality of any group of services. Availability immediately raises the questions of how much, to whom, and at what price. No single definition or scale of measurement can fully capture quality and availability and at the same time remain workable for purposes af analysis. Sone simplification, even oversimplification, is required to define and measure the concept in usable fashion.

one body of public finance literature points to collapsing quality and availability of public services into a single number: per capita expenditures on all public services or on a particular type of public service. ${ }^{1}$ This approach assumes that the more dollars spent on public services generally or on some particular public service, the higher the quality, the greater the availability, or both. It has the obvious shortcoming of substituting an input measure (dollars) for an output measure (services delivered). At the same time, however, this approach relies on data that is relatively easy to find and manipulate. And by reducing quality and 
availability of public services to a single number, it facilitates comparisons over time and among jurisdictions.

A second approach would define and measure the quality and availability of public services in terms of the actual services produced by government--books ordered, streets built, and so on. ${ }^{2}$ This approach has some apparent attraction. By focusing on outputs, it conveys a more accurate impression of services provided than the expenditurtes approach. But it complicates comparisons of quality and avallability over time and among jurisidictions. Because such comparisons are essential in expressing impacts one is quickly forced back to reliance on dollar expenditures.

Yet a third approach focuses on the allocation of particular inputs or outputs to particular social groups, "designated by income, race, and neighborhood." 3 This approach better expresses the concept of availability, at least at the level of social group. But it cannot be used without first specifying the inputs and outputs to be allocated.

For present purposes, it is probably appropriate to employ a definition broad enough to include all three approaches, narrowing the focus as necessary to perform particular analyses. Accordingly, we will adopt the following provisional definition and measure for quality and availability of public services: per capita expenditures on all services, or particular services, and the allocation of these services to particular social groups. Thus a government policy has an 
impact on the quality and availability of public services when the policy affects per capita expenditures on all services, per capita expenditures on particular services, or the allocation of services to particular social groups.

\subsection{DETERMINANTS}

What determines the quality and availability of public services in a particular community? There are basically two analytic traditions that offer help in addressing this question. One, the externally determined events approach, explains per capita expenditures on all public services or per capita expenditures on particular services as the result of social, economic, demographic, and political factors. The other, the bureaucratic process approach, explains expenditures on particular services and allocation of services to groups as the result of the municipal budgeting process. 4 Although overlapping, these two approaches are mostly complementary. The externally determined events approach is especially helpful in isolating the determinants of overall expenditures. The bureaucratic process approach is especially helpful in understanding the allocation of expenditures to particular services and groups.

\subsubsection{Public Services as Externally Determined Event}

The externally determined event aproach is nearly always used to explain public expenditures, either in the aggregate or 
on a particular public service, such as education. 5 The technique ordinarily employed is multiple regression analysis. The dependent variable is public expenditures. The independent variables--that is, the determinants of public expenditures--are a variety of social, political, economic, and demographic factors.

Stephen Barro and Gail Wilensky have each done literature reviews of studies using the externally determined event approach. 6 Generalizations from these studies are difficult, but wilensky has concluded that the following factors are generally important in determining per capita expenditures on all public services: ${ }^{7}$

Per capita income. As per capita income rises, so do expenditures on public services.

Intergovernmental aid. The more federal and state aid available to a local government, the more it spends on public services.

Population density. Population density is generally positively related to expenditures for public services.

Nonresident population. The greater a city's nonresident population, the more the city is likely to spend on public services.

Thus, in general, per capita expenditures on all public services are a function of per capita income, intergovernmental 
aid, population density, and nonresident population. of course, many studies have identified other factors as important too, especially in determining expenditures for particular services. Nonetheless, because they arise repeatedly in the various studies, these four determinants are reasonable choices for present purposes.

Barro has criticized this pure form of the external events approach for its failure to distinguish fiscal opportunities (a city's budget constraint) and the actual budgetary decisions made within that constraint. 8 In Barro's view, factors such as per capita income, intergovernmental aid, population density, and nonresident population act first to determine fiscal opportunities--i.e., "the levels of public services that can be supported at each given level of tax effort (or, equivalently...the level of tax effort that is required to support each level of public services)." 9 These same factors plus "local political factors" then determine local decisions about what use will be made of fiscal opportunities--i.e., about overall expenditures, expenditures on particular services, and allocation of services to particular groups. 10 In contrast to the pure form of the externally determined events approach, this perspective affords more hope of getting a handle on the allocation of expenditures to particular services and groups. Unfortunately, Barro does not specify how to operationalize his insight by specifying an approach for taking into account budgetary behavior. However, a different 
analytic tradition--that concerned with budgetary decisionmaking as a bureaucratic process--is a useful source of guidance.

\subsubsection{Public Services as Bureaucratic Output}

While the externally determined event approach primarily explains and predicts per capita expenditures on all public services (and sometimes per capita expenditures on particular services), the bureaucratic process approach is mainly useful in explaining per capita expenditures on particular services and the allocation of those services to social groups. Basically, this approach focuses on municipal budgeting, which is depicted as a sequential decision process that progresses from decisions about overall expenditures to decisions about departmental expenditures to decisions about the allocation of departmental expenditures. Each decision acts as a rigid constraint on subsequent decisions. Il In general, the process is stable over time, generates only incremental changes in expenditure patterns from year to year, and operates according to relatively crude decision rules.12 The upshot is that within the level of overall expenditures determined by the factors discussed in connection with the external events approach, the best guide to future departmental expenditures and their allocation to particular services and groups is the present pattern of departmental expenditures and allocation. Put simply, division of the pie is not very sensitive to 
increase of decrease in the size of the pie. In summary, the process works as follows.

\section{Overall Expenditures}

The first major decision in the annual budgetary sequence concerns public expenditures on all services. Since few local. jurisdictions may legally run an annual deficit, the level of revenues effectively determines the maximum level of expenditures that a local jurisdiction may undertake in a given year. Since a city may run a surplus, expenditures do not necessarily equal revenues, but they are a reasonable approximation.

Securing revenues, and thus determining aggregate expenditures, is the province of a city's "revenue subsystem"--the city manager or mayor, the financial staff or budget office serving him, and the city council. ${ }^{3}$ They have three main sources of revenue: taxes, borrowing, and intergovernmental transfers. In the short run, the sources, amounts, and terms and conditions of intergovernmental transfers are not very controllable by the revenue subsytem. The city has somewhat more control over borrowing, but the ability to borrow is still sharply constrained by legal requirements, such as the requirement that borrowing serve a municipal or public purpose, debt limitations or ceilings, and the city's authority to issue bonds. In borrowing, the city is also constrained by the marketability of its bonds, as determined by the bond market and the city's credit rating. 
In principle, the largest source of revenues-taxation--also seems to be the most flexible. In fact, the city's ability to increase tax revenues is also highly constrained. For a given set of taxes, tax base definitions, and tax rates, revenues are determined by the physical, economic, and demographic characteristics of the city. Moreover, a variety of legal and political constraints typically impede creation of new taxes, redefinition of tax bases, and increase in tax rates. The city can tax only within the scope of its authority, as provided in the state constitution, state statutes, and the city's own charter. Relevant limitations may concern the city's authority to tax non-residents, the reservation of certain taxing powers to the state, the requirement that taxes serve a public or municipal purpose, limitations on tax rates, and the requirement that voters approve rises in tax rates. Measures to increase tax revenues are further constrained by politics. Because the attentive "taxing publics" (those who care about taxes) are small, bureaucratic rather than electoral politics tend to dominate the search for new revenues. ${ }^{14}$ And the search process tends to be fragmented and superficial: the revenue subsystem essentially goes through the motions of searching for new sources of tax revenue. The dominant consideration is avoidance of taxpayer resistance. This is accomplished by "following the leader" (selecting only those new revenue sources for which there is successful precedent in other 
jurisdictions), levying indirect taxes (which are less visible), and emphasizing a large number of small taxes with low rates. ${ }^{15}$ The revenue subsystem also attempts to avoid uncertainty by adjusting the property tax yield to avoid a deficit through very conservative estimation of revenues. ${ }^{16}$ Overall, the system makes only incremental changes in tax categories, bases, and rates. As a consequence, revenues--and hence overall expenditures--do not vary much from year to year. And the changes that do occur rarely result from conscious political choice. Thus examination of the process that determines overall expenditures suggests that the process is mainly passive. Accordingly, the externally determined event approach is a reasonable way of predicting aggregate expenditures.

\section{Departmental Expenditures}

Based on expected revenues, the city manager or mayor typically provides guidance to the departments as to the aggregate levels within which they should prepare their budget requests. Typically, the departments respond with some limited gamesmanship. A favored tactic is to ask for more than can be reasonably expected in order to prevent undue cuts. Not ali departments behave this way, however. Some attempt to strike a balance between what they desire and what they can reasonably get. A few actually attempt to stay within the budget guidance. 17 
In general, the departments do not respond to changing pressures and demands for services in the external environment by attempting to drastically increase their budget share. Instead, they attempt to meet these demands within a fixed budget. ${ }^{18}$ In acting on departmental submissions to formulate the final budget, the revenue subsystem also tends to ignore external demands.19 In accordance with legal requirement to balance the budget, the revenue subsystem tends to pare down departmental requests to match revenues in accordance with arbitrary decision rules that ordinarily leave the relative budget shares of the various departments constant. Typically the city council ratifies the proposed budget of the manager or mayor. 20

The basic conclusion for municipal budgeting is the same as that of wildavsky for federal budgeting: even to the extent revenues contract or decline, the relative budget shares of the various departments remain roughly constant. 21 Next year's budget shares are proportional to this year's budget shares: $" t+1=t . "$

\section{Allocation to Services and Groups}

As in the previous stages of the budget process, departmental allocation of expenditures follows a principle of constancy, that is incremental change. 22 In general, departments allocate expenditures to services according to a political, technical, or professional criteria, which get 
formulated as rules of thumb. For example, Oakland's street engineers have selected projects according to the following decision rules: "(1) Improve or construct select streets only; (2) of these, improve and construct first those which provide access to freeways or will serve as cross-town arterials; (3) next, improve select streets that have heavy traffic, choosing (a) those which are congested and (b) those which are structurally unsound; (4) improve other select streets that are deficient in traffic-carrying capacity; (5) deal with emergency situations as they arise; (6) improve select streets in anticipation of future deficiencies (rarely used)."23 Political considerations--city policies and public opinion as reflected on the city council--impinge on these decision rules essentially as constraints. Unambiguous political signals may cause departments to reshuffle allocations of output as necessary to push them back into the range of political acceptability. 24 Departments do not anticipate political and other external pressures. Rather, they respond to them when made unambiguously clear. 25

In the short run, departments respond to political exigencies and changing costs and demands within their fixed budget. They do so by making incremental adjustments to service quantity, service quality, service cost, or by changing attention rules. 26 when it becomes necessary to cut outputs in order to meet changing demands in the short run or to satisfy an unexpectedly tight budget constraint, departments 
cut programs where cuts will not cause an immediate crisis, especially programs that have low visibility. 27

\subsubsection{Summary}

The principal determinants of quality and availability of public services are summarized in Figure 4.1. Overall expenditures on public services are determined by factors largely extraneous to the municipal budgetary process: per capita income, intergovernmental aid, population density, and nonresident population. Overall expenditures are then ordinarily allocated to each department on the basis of historical budget shares. When overall expenditures expand or contract, departmental expenditures tend to increase or decrease proportionally, so that relative budget shares remain little changed. Finally, departmental expenditures are allocated to particular services and groups largely on the basis of rules of thumb. When the cost of providing services or the need for services change, allocations are reshuffled in a manner that creates the least political heat.

\subsection{IMPACT OF FEDERAL ENERGY POLICIES}

The three illustrative federal energy policies affect the quality and availability of public services in different ways. Oil price decontrol has only a slight effect; BEPS affects the activities of municipal government directly by calling on them to participate in implementation; and federal aid to mass 
per capita income

- intergovernmental aid

- overaj.1 expenditures

- population density

- nonresident population

- overall expenditures

- historical proportions of overall expenditures allocated to each department

- departmental expenditures

- departmental expenditures

- allocation of departmental expenditures to

- cost of providing services

- rules of thumb

(e.g., cut low

visibility programs)

- strong political signals

FIGURE 4.1 Determinants of Quality and Availability of Public Services 
transit is explicitly targeted at the provision of a public service.

\subsubsection{Oil Price Decontrol}

Oil price decontrol, as manifested through higher gasoline and heating oil prices, could have several types of effects on the quality and availability of public services. These are essentially the same effects as those resulting from higher energy prices generally. For the reasons stressed before, the marginal contribution of oil price decontrol to these tendencies is Iikely to be small.

First, communities in oil producing states may experience increases in revenue, and thus in overall expenditures on public services. These increases would stem from increased per capita income among city residents (from oil revenues), increased intergovernmental aid from the state (because of increased severance and other tax revenues plus royalty payments and rents on state oil properties), and increased intergovernmental aid from the federal government (because of formulas that take into account state "tax effort" in federal aid programs.) 28

Second, in those communities where increased transportation and heating costs stimulate increased population density, overall expenditures on public services could increase. This effect seems likely to be quite small. 
Third, the cost to city departments in running public transportation, operating police, fire, and other vehicles, and in heating public buildings (in those communities relying on oil heat) will rise. It seems unlikely that the budgetary process would either reallocate funds from departments that use less energy or increase overall expenditures to meet these increased costs. Rather, each department whose energy bill rises is likely to have to cut back on energy using services (e.g., by reducing patrol car mileage or lowering building temperatures) or reduce other services. The particular services cut are likely to be those with the least visibility. Fourth, increased energy prices could create incentives for city governments to take energy considerations into account in reaching capital budgeting and improvements decisions. For example, city departments could be more sensitive to the energy implications of choices about whether to widen or pave a street, whether or where to build a new facility, whether to provide city services to an unsupplied area, and so on. 29 However, current understanding of city budgeting processes strongly suggests that incorporation of energy considerations into such decisions is likely to be the exception rather than the norm. Existing departmental decision rules are ordinarily too ingrained to respond with such a major modification to relatively small price signals, at least in the short run. Fifth, some have argued that rising energy prices wil? increase political participation generally. 30 This 
phenomenon could increase the visibility of capital budgeting and improvements decisions and perhaps over the middle to long $r$ un force agencies to adopt new decision rules more sensitive to energy considerations.

\subsubsection{Building Energy Performance Standards}

As was noted in section 2.3 .2 , the actions required by local governments will vary depending on which compliance path is chosen. The Alternate Approval Process (AAP) would require little more than rubber-stamping of design professionals' certifications by an authorized local government employee. The effects of this compliance option on the quality and availability of public services would be small. Compliance by administration and enforcement of state or local building energy codes would place larger burdens on local jurisdictions, particularly those jurisdictions required not merely to enforce state adopted Standards, but also to oversee development, implementation, and enforcement of equivalent local codes.

Local jurisdictions whose building departments are not already enforcing energy codes would have to develop new routines and procedures. Additional personnel might be needed to conduct plan reviews or site inspections as well as to answer technical questions and provide code interpretations. Procedures for administering penalties and handling appeals would also have to be developed and executed. Those jurisdictions that do not now enforce building codes, issue 
building permits, or conduct building inspections would first face the even more difficult and costly task of developing the capabilities to serve this regulatory function.

In short, BEPS implementation would place new demands on the city departments--chiefly building and planning agencies--required to take actions. In Colorado, for example, it has been estimated that "the long-term impact of energy Standards on the operational budget of building departments would average five percent varying between no effects in some jurisdictions to ten percent in others.... In Denver, $\frac{1}{4}$ it has been $\frac{1}{2}$ estimated that the increase in staff would equal between eight and nine percent of the existing staff, while in other jurisdictions it was felt that reorganization of the existing staff (i.e., doubling up of inspections) may be sufficient to cover increased manpower needs." 31 In pulaski county, Arkansas, the workload of the planning department has been predicted to increase 100 percent if the Standards were to be administered. 21

In principle, the budgets of the implementing agencies could be increased to provide funds for these new responsibilities--either by decreasing the expenditures of other departments or by increasing overall expenditures on public services. In fact, the workings of the budgetary process are likely to prevent this result, except for feceral aid directly targeted at BEPS implementation. For the rest, the implementing departments will have to levy fees or cut 
their other services, such as the performance of building inspections generally. Some combination appears the likeliest result.

\subsubsection{Federal Aid to Mass Transit}

As a form of intergovernmental aid, federal aid for mass transit directly increases overall expenditures for public services. While there is some tendency for the revenue subsystem to attempt to substitute intergovernmental aid for other revenue sources, and thus keep overall expenditures constant while reducing the tax burden, aid formulas are generally drafted to preclude full substitution le.g., through matching requirements). Because these funds are keyed to expenditures on transportation, they are likely to increase the budget share of the city departments responsible for providing public transportation, despite the tendency of the budgeting process to preserve stable budget shares. The allocation of these funds to particular transit services is impossible to predict in the abstract. However, the decision rules of most transit agencies probably favor the rehabilitation and expansion of existing systems rather than the creation of new mass transit systems. 


\section{FOOTNOTES TO CHAPTER ONE}

1. 43 Fed. Reg. 37,779 (August 24, 1978).

2. Gail Wilensky, "Determinants of Local Government

Expenditures," in John P. Crecine ed., Financing the Metropolis (Beverly Hills: Sage Publications, 1970), p. 204.

3. Congress of the United States, Congressional Budget Office, The Decontrol of Domestic Oil Prices: An Overview (Washington, D.C.: Government Printing Office, May 1979), pp. 68-69. 
•

. 
1. Suzanne Keller, The Urban Neighborhood: A Sociological Perspective, (New York: Random House, 1968), pp. 87-92.

2. Gale Cinotta, National People's Action, in Statement before U.S. Senate, Committee on Banking, Housing and Urban Affairs, Neighborhood Preservation. 94th Congress, 2nd Session, June 14, 1976, p. 36.

3. Peter H. Mann, "The Neighborhood," in Robert Gutman and David Popenoc (Eds.) Neighborhood, City, and Metropolis, (New York: Random House, 1970), pp. 568-583.

4. Scott Greer, "Neighborhood," in David L. Sills (Ed.) International Encyclopedia of the Social Sciences, (The Macmillan Co. and The Free Press, 1968).

5. Morris Janowitz and David Street, "Changing Social Order of the Metropolitan Area," in David Street and Associates, Handbook of Contemporary Urban Life, (San Francisco: Josey-Bass, 1978), pp. 90-128.

6. Peter D. Miller, "Stability, Diversity, and Equity: A Comparison of Coal, Oil shale, and Synfuels," in Charles T. Unseld, et al. (Eds.) Sociopolitical. Effects of Energy Use and Policy, (Washington, D.C.: National Academy of Sciences, 1979), p. 167.

7. Brian J. L. Berry and John D. Rasarda, Contemporary Urban Ecology, (New York: Macmillan Publishing Company, 1977), pp. 85-93.

8. Kent P. Schwirian, "Internal Structure of the Metropolis" in Rent P. Schwirian (Ed.) Contemporary Topics in Urban Sociology, (Morristown, N. J.: General Learning Press, 1977), pp. 152-215.

9. Public Affairs Counseling, The Dynamics of Neighborhood Change, Prepared for the U.S. Department of Housing and Urban Development (HUD-PDR-108(2)), (San Francisco, December, 1975), p. 8.

10. Berry and Kasarda, Op. cit., p. 58.

11. Ibid., Op. cit., p. 53-71.

12. Carl R. Griffith, "Assessing Community Cohesion Impact Through Network Analysis," Journal of Environmental Systems, Vol. 9(2), 1979-80. 
13. Peter A. Morrison, "Population Movements and the Shape of Urban Growth: Implications for Public Policy," in Sara Mills Mazie (Ed.) Population, Distribution, and Policy, Vol. 5, The Commission on Population Growth and the American Future, (Washington, D.C.: Government Printing Office, 1972), p. 289.

14. PauI R. Porter, "The Neighborhood Interest in a City's Recovery," Journal of the American Planning Association, Vol. 45(4), October, 1979, p. 474 .

15. Public Affairs Counseling, Op. cit., Figure 1, p. 9.

16. Peter A. Morrison with Judith P. Wheeler, "Rural Renaissance in America? The Revival of Population Growth in Remote Areas," Population Bulletin, Vol. 31(3), Population Reference Bureau, Inc., October, 1976, p. 3 .

17. Ernest $W$. Burgess, "The Growth of the City: An Introduction to a Research Project," in R. E. Park, E. W. Burgess, and R. D. MCKensie (Eds.), The City, (Chicago: University of Chicago Press, 1925).

18. Avery M. Guest and Christopher Cluett, "Metropolitan Retail Nucleation," Demography, Vol. 11(3), August, 1974.

19. Jeanne C. Biggar, "The Sunning of America: Migration to the Sunbelt," Population Bulletin, Vol. 34(1), Population Reference Bureau, Inc., March, 1979.

20. Porter, op. cit., p. 478-9.

2I. Glenn V. Fuguitt and James J. Zuiches, "Residential Preferences and Population Distribution," Demography, Vol. $12(3)$, August, 1975.

22. Neil N. Gold, "The Mismatch of Jobs and Low-Income People in Metropolitan Areas and Its Implications for the Central-City Poor," in Sara Mills Mazie (Ed.) Population, Distribution, and Policy, Vol. 5, The Commission on Population Growth and the American Future, (Washington, D.C.: Government Printing office, 1972).

23. Alden Speare, Jr., "Residential Satisfaction as an Intervening Variable in Residential Mobility, "Demography, Vol. 11(2), May, 1974 .

24. Avery M. Guest, "Residential Segregation in Urban Areas," in Kent P. Schwirian (Ed.) Contemporary Topics in Urban Sociology, (Morristown, N. J.: General Learning Press, 1977). 
25. Public Affairs Counseling, Op. cit.

26. Gerald D. Suttles, The Social Construction of Communities, (Chicago: The University of Chicago Press, 1972).

27. Porter, Op. cit., p. 477.

28. Guest, 1977, op. cit., p. 319.

29. Anthony Downs, "Key Relationships Between Urban Development and Neighborhood Change," Journal of the American Planning Association, Vol. 45(4), October, 1979, p. 465 .

30. Public Affairs Counseling, Op. cit.,

31. Ibid, p. 21 .

32. Suttles, Op. cit., p. 11 .

33. Philip M. Hauser, "On the Impact of Urbanism on Social Organization, Human Nature and the Political Order," in Robert Gutman and David Popenoe (Eds.) Neighborhood, City, and Metropolis, (New York: Random House, 1970).

34. Irving A. Speigel, "Organizing the Local Community: The Social-stability Approach," in Fred M. Cox, et al. (Eds.) Strategies of Community Organizations, (Illinois: Peacock Publishers, Inc., 1979).

35. Douglas Yates, Neighborhood Democracy, (Massachusetts: Lexington Books, (1973).

36. Howard $w$. Hallman, The Organization and Operation of Neighborhood Councils: A Practical Guide, (New York: Holt, Rinehart and winston, 1978).

37. Marvin E. Olsen, The Process of Social Organization: Power in Social systems, (New York: Holt, Rinehart and winston, 1978).

38. Janowitz and street, op. cit., p. 93.

39. Congress of the United States, Congressional Budget Office, The Decontrol of Domestic Oil Prices: An Overview (Washington, D.C.: Government Printing Office, May, 1979), p. 14.

40. Ibid., pp. 68-69.

41. Ibid., p. 69 . 
42. Ibid., pp. 68-69.

43. Ibid.

44. Ibid.

45. Richard Corrigan and Rochelle I. Stanfield, "Rising Energy Prices-what's Good for Some States is Bad for Others," National Journal, March 22, 1980.

45. Congressional Budget office, p. 67 .

47. Ibid., p. 64 .

48. James O'Toole, Energy and Social Change (Cambridge, Mass.: MIT Press, 1976), p. 67.

49. See B. Bruce-Briggs, "Gasol ine Prices and the Suburban Way of Life," The Public Interest, (1974).

50. Anthony Downs, "Squeezing Spread City," New York Times Magazine (March 17, 1974), pp. 34-47; and Steve Weiner, "Soaring Gasoline Prices Mess Up the Good Iife in the Distant Surburbs," Wall Street Journal (March 12, 1980), p. 1 .

51. O'Toole.

52. Congressional Budget Office, p. 67 .

53. Sawyer et al., An Analysis of Institutional Issues in the Implementation of Federal Energy Performance Standards for New Buildings, PNL-3312 (Battelle Pacific Northwest Laboratory, March, 1980), pp. 1.2, 1.5.

54. U.S. Department of Energy, Office of Conservation and Solar Energy, Office of Buildings and Community systems, Draft Environmental Impact Statement: Supplement; Energy performance Standards for New Buildings, Washington, D.C., February, 1980, pp. C-38, C-39, C-4I.

55. Ibid., p. C-I5.

56. Ibid., pp. $C-28, c-30$. 
57. Ibid., p. 3.23 .

58. Ibid., pp. C-28, C-30.

59. Richard Corrigan, "The Money-Making Machine," National Journal, July 21, 1979, p. 1219.

60. Richard Corrigan, "There's Not Much for Production from the $\$ 227$ billion 'Windfall' Tax," National Journal, February 23, 1980, pp. 314-316.

61. Harvard Business School, "The Environment of the Transit Industry" (1974), and Environmental Quality: The Sixth Annual Report of the Council on Environmental Quality, December, 1975, PP. 171-174.

62. Rochelle L. Stanfield, "'Windfall Profits' Tax Revenues May Be Salvation for Mass Transit," National Journal, September 22, 1979.

63. Ibid.

64. Some of the controversy about how to allocate mass transit spending can be found in Congressional Budget office, The Decontrol of Domestic Oil Prices; also see George Shelton, Federal Transit Subsidies: The Urban Mass Transportation Assistant Program (Washington, D.C.: American Enterprise Institute for Public Policy Research, 1974) and Charies A Lave, "Transportation and Energy," Policy Analysis, Sommer, 1978, pp. 297-315.

65. Sawyer, et al., pp. 10.3-10.14.

66. Stanfield.

67. Ibid.

68. U.S. Congress, Senate, Subcommittee on Transportation, Committee on Environment and Public Works, Hearings, Urban Transportation and Energy: A Potential Savings of Different Modes, October 5, 1977, pp. 11, 29, 30.

69. Lave, p. 298.

70. Urban Transportation and Energy, pp. 11, 29, 30.

71. Ibid., p. 4 . 
72. Sid Davis, "Housing Locational Choice Implications of Rapid Transit Expenditures" Review of Regional Studies (Fall 1976), p. 15.

73. Gary R. Fauth and Jose A. Gomez-Ibanez, "Demographic Change, New Location Patterns, and Transportation Policy" in Berry and Silverman (eds.), Population Redistribution and Public Policy (Washington, D.C.: National Academy of Sciences, 1980), p. 170, 193-4; See al so Alan Altschuller and James P. Womack, "The Urban Transportation System: Policies and Policy Innovation" APA Journal (October, $1979)$, p. 580.

74. John F. Rain, "The Journey to Work as a Determinant of Residential Location," Papers and Proceedings of the Regional Science Association. 1969, pp. 137-160.

75. Lave, pp. 297-315.

76. Gregory S. Lipton, "Evidence of Central City Revival", American Institute of Planners Journal April, 1977, pp. 136-147 as cited in Robert J. Vaughan and Mary E. Vogel, The Urban Impacts of Federal Policies: Vol. 4, population and Residential Location (Santa Monica: Rand Corporation, 1979). 
1. Edwin S. Mills, Urban Economics (Glenview, III: Scott, Foresman and Co., 1972), p. 165 .

2. Richard S. Conway, Jr. and Charles T. Howard, "Forecasting Regional Housing Investment," draft of a paper for washington State Department of Commerce and Economic Development, p. 2 .

3. Edgar Ol Olsen, "A Competitive Theory of the Housing Market" in Jon Pynoos, Robert Schafer, and Chester W. Hartman (eds.), Housing Urban America (Chicago: Aldine, 1973), pp. 228-29.

4. Milis, p. 179.

5. Ibid.

6. Olsen, p. 229 .

7. Ibid

8. See John Kain and John Quigley, "Measuring the Value of Housing Quality," Journal of American Statistical Association

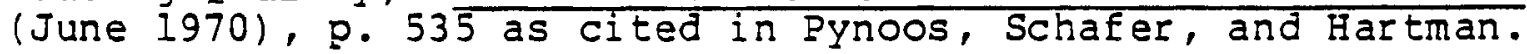

9. Ibid.

10. Olsen, p. 228 .

11. Ibid.

12. Richard Muth, Cities and Housing (Chicago: University of Chicago Press, 1969); Chester Rapkin, "Price Discrimination Against Negroes in the Rental Market" in Pynoos, Schafer, and Hartman, pp. 290-97; Ann B. Schnare and C. Duncan Macrae, "The Dynamics of Neighborhood Change" Urban Studies (1978):327-331.

13. See Pynoos, Schafer, and Hartman, p. 205

14. E.A. Hanushek, and J.M. Quigley, "The Dynamics of the Housing Market: A Stock Adjustment Model of Housing Consumption," Journal of Urban Economics, 6(1979):90-111; G. Carliner, "Income Elasticity of Housing Demand," The Review of Economics and Statistics, 55(1973):528.532; F. Deleeuw, "The Demand for Housing: A Review of Cross-Section Evidence," The Review of Economics and Statistics 53(1971):1-10; T.H. Lee, "The Stock Demand Elasticities of Non-Farm Housing," The Review 
of Economics and Statistics 46(1964):82-89; T.H. Lee and C.M. Kong, (1977) "Elasticities of Housing Demand," Southern Economic Journal 44(1977):298-305; S.J. Maisel, J.B. Burnham, J.S. Austin, (1971), "The Demand for Housing: A Comment," The Review of Economics and Statistics 53(1971):410-413; R.F. Muth, "The Demand for Non-Farm Housing," in Harber, A.C. (ed.), The Demand for Durable Goods. (Chicago: University of Chicago Press:1960) A.M. Polinsky, "The Demand for Housing: A study in Specification and Grouping," Econometrica 45(1977):447-461; M. Reid, Housing and Income, (Chicago: University of Chicago Press: 1962) G.A. Vaughn, "Sources of Downward Bias in Estimating the Demand Income Elasticity for Urban Housing," Journal of Urban Economics, 3(1976):45-55.

15. C. Almon, et al., (1974), 1985: Interindustry Forecasts of the American Economy, Lexington, Mass. (Lexington, MA: Lexington Books, 1974) R.S. Conway, Jr. and C.T. Howard, (1977), "A Forecasting Model of Regional Housing Construction," unpublished; F. Deleeuw, "The Demand For Housing: A Review of Cross-Section Evidence," The Review of Economics and Statistics, 53(1971):1-10; J.R. Follian, "The Price Elasticity of the Long-run Supply of New Housing Construction," Land Economics, 55(1979):190-199; R.S. Preston, The wharton Annual and Industry Forecasting Model. (Philadelphia: University of Pennsylvania, 1975)

16. E.S. Mills, "An Aggregate Model of Resource Allocation in Metropolitan Area," American Economic Review, 57(1967):197-210; R.F. Muth, "The Demand for Non-Farm Housing," in Harber, A.C. (ed.), The Demand for Durable Goods, (Chicago: University of Chicago Press(1960)) M.K. Evans, Macroeconomic Activity: Theory, Forecasting and Control, (New York: Harper and Row(1969)) M. Fujita, "Spatial Patterns of Urban Growth; Optimum and Market," Journal of Urban Economics, 3(1976):209-24I; D.A. Livesey, "Optimum City Size: A Minimum Congestion Cost Approach," Journal of Economic Theory, l(1974):230-279; J.G. Riley, "Optimal Residential Density and Road Transportation", Journal of Urban Economics, I (1974):230-279; S. Rose-Ackerman, "The Political Economy of a Racist Housing Market," Journal of Urban Economics, 4(1977):150-169; E. Sheshinski, "Congestion and Optimum City Size," American Economic Review, 63(1973):61-70; R.M. Solow, "Congestion, Density and the Use of Land in Transportation," Swedish Journal of Economics, 74(1972):161-173.

17. Olsen, p. 229 .

18. Ibid.

19. See Anthony Downs, "Public Policy and the Rising Cost of Housing" Real Estate Review (1978):27-38; and James R. Follain, 
Jr. and Raymond J. Struyk, "Is the American Dream Really

Threatened?" Real Estate Review 4(1979):65-70.

20. Rochelle L. Stanfield, "For Housing Light At the End of The Tunnel," National Journal (April, 19, 1980(, p. 630.

21. Downs, pp. 27-38.

22. Ibid.

23. Mills, p. 164 .

24. Ibid., p. 163

25. Ibid., P. 183

26. Ibid., p. 180-81

27. See, Edward C. Banfield, The Unheavenly City: The Nature and Future of Our Urban Crisis (Boston: Little, Brown and Company, 1968), pp. 23-45; Roger J. Vaughan and Mary E. Vogel, The Urban Impacts of Federal Policies: Vol. 4, Population and Residential Location (Santa Monica: Rand, 1979); M.D. Cadwallader, "The Urban Impact of Federal Policies" Environment and Planning (April, 1979):40; David L. Birch et al., The Behavioral Foundations of Neighborhood Change (Washington, D.C.: HUD, 1979); M.T. Cadwallader, "Neighborhood Evaluation in Residential Mobility," Environment and Planning (1979):393-40I; and John L. Goodman, Jr. "Reasons for Moves out of and Into Large Cities" APA Journal (October 1979):407-416.

28. Banfield's purpose is to argue that population changes, along with economic and technological development and race and class, place "stringent limits on policy." Banfield, p. 41.

29. William Alonso, "Metropolis Without Growth," The Public Interest (Fall 1978):71.

30. Stanfield, p. 629.

31. Ibid.

32. Ibid.

33. See Vaughan and Vogel, pp. 33-34; also see Col in Jones, "Housing: the Element of Choice," Urban Studies (1979):197-204.

34. Vaughan and Vogel, p. 59; also see Arden C. Brummel, "A Model of Intraurban Mobility," Economic Geography (1979) : 338-352. 
35. Ibid., p. 33.

36. Ibid.

37. Ibid., p. 72

38. Ibid.

39. Ibid., p. 73 .

40. Diane Ravitch, "The 'White Flight' Controversy," The Public Interest (Spring, 1978):135-50.

41. Ibid., P. 145; Also see Christine H. Rossel, Diane Ravitch, David J. Armor, "Bussing and white Flight," The Public Interest (Fall 1978):109-116.

42. Mills, p. 163.

43. Ibid.

44. Ibid.

45. Conway and Howard, p. 2.

46. Mills, p. 185.

47. Ibid.

48. Ibid., p. 183.

49. Ibid., p. 182.

50. Pynoos, Schafer, and Hartman, p. 299. Also, see James W. Doig and Michael N. Danielson, "Government's Impact on Urban Development," Policy Studies Journal (Summer 1980):852-62.

51. Ibid., p. 300. See refutation of this view by A.L. Stinchcombe," Bureaucratic and Craft Administration of Production," Administrative Science Quarterly (September 1959): 168-187.

52. Bernard J. Frieden, The Environmental Protection Hustle (Cambridge: MIT Press, 1979) as cited in Stanfield. Also see Sally $R$. Fairfax's essay in Ecology Law Quarterly $(1980): 583-593$.

53. See Stephen R. Seidel, Housing Costs and Government Regulations (New Brunswick: Center for Urban Policy Research, 1978), Chapter 12. 
54. David E. Dowall, "The Effect of Land Use and Environmental Regulations on Housing Cost," Policy Studies Journal

(1979): 277-288.

55. Pynoos, Schafer, and Hartman, p. 303.

56. Ibid.

57. See Anthony's Downs, "Sqeezing Spread City," New York Times Magazine 3/17/74, p. 38; and Steve Weiner, "Soaring Gasoline Prices Mess Up the Good Iife in the Distant Surburbs," Wall street Journal (March 12, 1980) p. I.

58. See Stanfield.

59. See Downs and Weiner.

60. See discussion of Building Energy Performance Standards which follows.

61. See Dowall; Also see Mary E. Brooks, Housing Equity and Environmental Protection: The Needless Conflict (Washington, D.C.: American Institute of Planning, 1976.)

62. Draft EIS: Supplement; Energy Performance Standards for New Buildings. U.S. Department of Energy, Office of Conservation and Solar Energy, Office of Buildings and Community Systems, washington, D.C., February 1980, p. C.I5.

63. Markin Klepper, "The National Energy Act: Its Impact on Real Estate," Real Estate Review 9(1979):40-49. See also Martin Klepper, "Real Estate and Energy," Real Estate Review, $9(1980): 24-25$.

64. Draft EIS: Supplement; Energy Performance Standards for New Buildings. pp. C. 4 and C. 5 .

65. Ibid.

66. Ibid.

67. Ibid.

68. Ibid.

69. Draft EIS: Supplement: Energy Performance Standards for New Buildings. p. C.31.

70. Draft EIS: Supplement; Energy Performance Standards for New Buildings. p. C. 28 . 
71. Draft EIS: Supplement; Energy Performance Standards for New Buildings. p. C.30.

72. Sid Davis, "Housing Locational Choice Implications of Rapid Transit Expenditures," Review of Regional Studies (Fall $1976: 1-16$.

73. Quoted by Davis, p. 2; from Urban Mass Transportation Administration, U.S. Department of Transportation, Metropolitan Atlanta Rapid Transit Authority: Final Environmental statement (March 1973).

74. Ibid., p. 2 
13. Arnold J. Meltsner, The Politics of City Revenue (Berkeley: University of California Press, 1971), p. 71.

14. Meltsner, p. 60.

15. Meltsner, pp. 101-106.

16. Meltsner, pp. 114-124.

17. Meltsner, pp. 171-172.

18. Crecine, p. 188.

19. Crecine, pp. 191, 192-193.

20. Crecine, p. 207, Meltsner, p. 68.

21. Wildavsky, p. 13.

22. Levy et al,, pp. 46,112 .

23. Levy et al,, pp. 119-120.

24. Levy et al., pp. 121-132.

25. Levy et al., p. 119.

26. Crecine, pp. 190, 203.

27. Levy et al., pp. 46-47;185.

28. Richard Corrigan and Rochelle L. Stanfield, "Rising Energy Prices-What's Good for Some States is Bad for Others, National Journal, March 22, 1980.

29. See Statement of Marion L. Hemphill, Acting Energy Advisor, City of Portland Oregon, U.S. Congress, House of Representatives, subcommittee on the City of the committee on Banking, Finance and Urban Affairs, 95 th Congress, ist session, September 14, 1977, p. 106.

30. James O'Toole, Energy and Social Change (Cambridge, MA: The MIT Press, 1976), p. 151.

31. Sawyer, et al., An Analysis of Institutional Issues in the Implementation of Federal Energy Performance Standards for New Buildings, PNI-3312 (Battelle Pacific Northwest Laboratories, March 1980), p. 10.13 .

32. Sawyer, et a.1, p. 10.14. 
, 
1. Frank S. Levy, Arnold J. Meltsner, and Aaron Wildavsky, Urban Outcomes (Berkeley: University of California Press, 1974), P. 11 .

2. Levy et al., pp. 6, 8 .

3. Levy et al., p. 4.

4. The distinction between public services as externally determined event and public services as bureaucratic output follows John P. Crecine, Governmental Problem-Solving: A Computer Simulation of Municipal Budgeting (Chicago: Rand MaNally, 1969), pp. 12-19.

5. Levy et al., p. 11 .

6. Stephen M. Barro, The Urban Impacts of Federal Policies: Vol. 3, Fiscal Conditions, R-2114-KF/HEW (The Rand Corporation, April 1978); Gail Wilensky, "Determinants of Local

Expenditures," in John P. Crecine ed., Financing the Metropolis (Beverly Hills: Sage Publications, 1970).

7. Wilensky, p. 204 .

8. Barro, pp. 28-29.

9. Barro, p. 28 .

10. Barro, pp. 28-30.

11. Crecine, pp. 186-192.

12. Bureaucratic models of the municipal budgetary process are developed in Crecine; Levy et al.; and Arnold J. Meltsner, The Politics of City Revenue (Berkeley: University of California Press, 1971.) They resonate strongly with Aaron Wildavsky, The Politics of the Budgetary Process, Second Edition (Boston: Little, Brown, 1974), which examines federal budgeting, and with the "Carnegie School" organization theorists. The relevant theoretical works include Henry A. Simon, Administrative Behavior (New York: The Free Press, 1965), James G. March and Henry A. Simon, Organizations (New York: Wiley, 1958), Richard M. Cyert and James G. March, A Behavioral Theory of the Firm (Englewood Cliffs, NJ: Prentice-Hall, 1963), and Charles E. Lindblom, "The Science of 'Muddling Through'," Public Administration Review, Spring 1959. 
• 


\section{DISTRIBUTION}

No. of

Copies

\section{OFFSITE}

A. A. Churm

Department of Energy

Chicago Patent Group

9800 South Cass Avenue

Argonne, II 60439

27 Department of Energy

Technical Information Center

S. Ballou

Argonne National Laboratory

9700 South Cass Avenue

Argonne, IL 60439

R. Clusen

Assistant Secretary for Environment Department of Energy (M/S E-20I)

Washington, DC 20545

J. A. Coleman

office of Environmental Assessments Department of Energy (M/S E-20I)

washington, DC 20545

R. M. Davis

Oak Ridge National Laboratory

P. O. BOX X

Oak Ridge, TN 37830

A. R. Evans

Argonne National Laboratory

9700 South Cass Avenue

Argonne, IL 60439

W. Fulkerson

Oak Ridge National Laboratory

P. O. Box X

Oak Ridge, TN 37830

J. F. Hinkle

Office of Environmental Assessments

Department of Energy (M/S E-20I)

Washington, DC 20545
No. of

Copies

T. Harris

Office of Environmental Assessments

Department of Energy (M/S E-20I)

Washington, DC 20545

P. W. House

Office of Environmental Assessments

Department of Energy (M/S E-20I)

washington, DC 20545

J. Jaksch

Los Alamos Scientific Laboratory

University of California

P. O. Box 1663

Los Alamos, NM 87545

R. K. Lohrding

Los Alamos Scientific Laboratory

University of California

P. O. Box 1663

Los Alamos, NM 87545

P. M. Meier

Building 475

Brookhaven National Laboratory

Associated Universities, Inc.

Upton, NY 11973

D. M. Monti

Office of Envirormental Assessments

Department of Energy (M/S E-20I)

washington, DC 20545

P. Moskowitz

Brookhaven National Laboratory

Associated Universities, Inc.

Upton, NY II973

A. Rudolph

Battelle Memorial Institute

505 King Avenue

Columbus, OH 43201

Dist-I 
No. of

Copies

R. D. Shull

Office of Environmental Assessments

Department of Energy (M/S E-201)

Washington, DC 20545

W. E. Siri

Lawrence Berkeley Laboratory

University of California

Berkeley, CA 94720

E. R. Williams

Office of Environmental Assessments

Department of Energy (M/S E-201)

Washington, DC 20545

$\underline{\text { ONSITE }}$

DOE-RICHLAND

H. E. Ransom

BATTELLE-HUMAN AFFAIRS RESEARCH CENTERS

C. Cluett

B. Keen

D. Keller

B. Louzin-Library Services/HARC

A. Marcus

F. Morris

PACIFIC NORTHWEST LABORATORY

W. J. Bair

D. L. Hessel (10)

I. S. Levy

S. Marks

Economics Library (5)

Publishing Coordination (2)

Technical Information $F$ iles (5) 